Hydrol. Earth Syst. Sci., 17, 1-20, 2013

www.hydrol-earth-syst-sci.net/17/1/2013/

doi:10.5194/hess-17-1-2013

(C) Author(s) 2013. CC Attribution 3.0 License.

\title{
Impact of climate change on sediment yield in the Mekong River basin: a case study of the Nam Ou basin, Lao PDR
}

\author{
B. Shrestha ${ }^{1}$, M. S. Babel ${ }^{1}$, S. Maskey ${ }^{2}$, A. van Griensven ${ }^{2,3}$, S. Uhlenbrook ${ }^{2,4}$, A. Green ${ }^{5}$, and I. Akkharath \\ ${ }^{1}$ Water Engineering and Management, School of Engineering and Technology, Asian Institute of Technology, \\ P.O. Box 4 Klong Luang, Pathum Thani 12120, Thailand \\ ${ }^{2}$ Department of Water Science and Engineering, UNESCO-IHE Institute for Water Education, P.O. Box 3015, \\ 261DA Delft, The Netherlands \\ ${ }^{3}$ Department of Hydrology and Hydraulic Engineering, Vrije Universiteit Brussels, Pleinlaan 2, 1050 Brussels, Belgium \\ ${ }^{4}$ Department of Water Resources, Delft University of Technology, P.O. Box 5048, 2600 GA Delft, The Netherlands \\ ${ }^{5}$ Mekong River Commission Secretariat, Office of the Secretariat in Phnom Penh (OSP), P.O. Box 623, \\ 576 National Road \# 2, Sangkat Chak Angre Krom, Khan Menachey, Phnom Penh, Cambodia
}

Correspondence to: B. Shrestha (bikeshs1983@gmail.com)

Received: 21 February 2012 - Published in Hydrol. Earth Syst. Sci. Discuss.: 14 March 2012

Revised: 19 November 2012 - Accepted: 30 November 2012 - Published: 7 January 2013

\begin{abstract}
This paper evaluates the impact of climate change on sediment yield in the Nam Ou basin located in northern Laos. Future climate (temperature and precipitation) from four general circulation models (GCMs) that are found to perform well in the Mekong region and a regional circulation model (PRECIS) are downscaled using a delta change approach. The Soil and Water Assessment Tool (SWAT) is used to assess future changes in sediment flux attributable to climate change. Results indicate up to $3.0^{\circ} \mathrm{C}$ shift in seasonal temperature and $27 \%$ (decrease) to $41 \%$ (increase) in seasonal precipitation. The largest increase in temperature is observed in the dry season while the largest change in precipitation is observed in the wet season. In general, temperature shows increasing trends but changes in precipitation are not unidirectional and vary depending on the greenhouse gas emission scenarios (GHGES), climate models, prediction period and season. The simulation results show that the changes in annual stream discharges are likely to range from a $17 \%$ decrease to $66 \%$ increase in the future, which will lead to predicted changes in annual sediment yield ranging from a $27 \%$ decrease to about $160 \%$ increase. Changes in intra-annual (monthly) discharge as well as sediment yield are even greater ( -62 to $105 \%$ in discharge and -88 to $243 \%$ in sediment yield). A higher discharge and sediment flux are expected during the wet seasons, although the highest relative changes are observed during the dry months. The
\end{abstract}

results indicate high uncertainties in the direction and magnitude of changes of discharge as well as sediment yields due to climate change. As the projected climate change impact on sediment varies remarkably between the different climate models, the uncertainty should be taken into account in both sediment management and climate change adaptation.

\section{Introduction}

Changes in climate have been observed in the past decades, and more changes have been projected for the coming decades (IPCC, 2007). Climate models estimate that the global mean atmospheric temperature is likely to increase by 1.8 to $4.0^{\circ} \mathrm{C}$ by the end of the 21 st century, depending on various greenhouse gas emissions scenarios (GHGES) and general circulation models (GCMs) (IPCC, 2007). An increase in global temperature is expected to increase evapotranspiration and to cause precipitation changes (Hu et al., 2012), which will significantly affect the hydrological regimes of many river systems (Lu, 2005). Many studies have shown that climate change could significantly affect streamflow (Nijssen et al., 2001; Menzel and Burger, 2002), soil erosion rates (Pruski and Nearing, 2002; Michael et al., 2005; O'Neal et al., 2005) and sediment flux (Xu, 2003; Syvitski et al., 2005; Zhu et al., 2008). For instance, Zhu et al. (2008) have 
estimated a change in sediment flux from -0.7 to $13.7 \%$ as a result of changes in rainfall ranging from -0.7 to $17.8 \%$ and temperature fluctuation of $0.03-2.4{ }^{\circ} \mathrm{C}$ in the Longchuanjiang catchment of the Upper Yangtze River, China. Similarly, Pan et al. (2011) have reported 1 to $3 \%, 3.9$ to $11.4 \%$ and -1.1 to $-5.3 \%$ changes in mean annual, wet season and dry season streamflows respectively and 1.2 to $4.7 \%, 3.6$ to $15.3 \%$ and -1.3 to $-7.7 \%$ changes in mean annual, wet season and dry season sediment yields respectively for the Song Cau watershed in northern Vietnam due to the changes in precipitation and temperature under B1, B2, and A2 climate change scenarios.

The effects of climate change are studied in an area that belongs to the Mekong River basin. The Mekong is the largest river in Southeast Asia and drains a catchment of $795000 \mathrm{~km}^{2}$ (Mekong River Commission, 2005) with China, Thailand, Lao PDR, Cambodia, Vietnam and Myanmar as its riparian countries. Several climate change studies of the Mekong River basin have projected a likely increase in the basin's mean temperature and annual rainfall. For instance, Eastham et al. (2008) conducted a study to investigate the likely climate changes in the Mekong basin by the year 2030, and the results show a possible increase in the basin's mean temperature by $0.79^{\circ} \mathrm{C}$ and a $13.5 \%$ increase in annual precipitation resulting mainly from an increase in the wet season's (May to October) precipitation in all the subcatchments. Apart from the climate change issue, the basin is currently facing other challenges too: the population is growing; urban sectors are expanding; and the economies of riparian countries are developing rapidly (Keskinen, 2008). Water development projects, most notably the construction of large hydropower dams, are important for economic development (Mekong River Commission, 2006), and hence extensive programs and plans are underway to build reservoirs in the tributaries as well as the mainstream areas within the riparian countries (Mekong River Commission, 2008).

The sediment load of a river is sensitive to both climate and a wide range of human activities within its drainage basin. These factors could influence sediment mobilization and transfer through actions like clearing of land, agricultural development, mineral extraction, urbanization and infrastructure development, dam and reservoir construction, and soil conservation and sediment control programs (Walling, 2008). Although the sediment of the Lower Mekong River has critical implications for aquatic ecology - fisheries, agriculture, water supply and river navigation - studies of the generation, transportation and deposition of sediment in the Lower Mekong are sparse (Wang et al., 2011). Previous studies (Ishidaira et al., 2008; Kiem et al., 2008; Hoanh et al., 2010; Kingston et al., 2011) of the hydrological impacts of potential climate changes in the Mekong have generally focused on flow in the river. The potential future changes in sediment load should be seen as an important requirement for sound river basin management (Walling, 2008). While researchers have highlighted the significant potential of climate change in increasing global soil erosion rates and possibly leading to increasing amounts of suspended sediment flux in rivers, the actual response of suspended sediment flux in a particular place varies because it is also highly affected by the physical characteristics of the catchment and human activities in it (SWCS, 2003; Zhang and Nearing, 2005). In any case, there is a clear need for improved understanding of the potential impact of climate change on the sediment load in the Mekong River basin. Further, the possible changes in the sediment load need to be evaluated in order to understand the implications on future reservoir development and to assess the changes' effects on future management strategies (as outlined by Walling, 2008).

Reliable predictions of the quantity and rate of runoff, and sediment transport from land surfaces into streams, rivers and other water bodies are needed to help decision makers in developing watershed management plans for better soil and water conservation measures (Setegn et al., 2010) and to assess potential future implications due to the factors driving the changes. For this, several available mathematical models can be used. Of these, the Soil and Water Assessment Tool (SWAT) has been employed widely to evaluate the impact of climate change on soil erosion and sediment flux (Zhu et al., 2008). For example, Li et al. (2011) applied SWAT to evaluate the effect of temperature change on water discharge, and sediment and nutrient loading in the Lower Pearl River basin, China. Hanratty and Stefan (1998) and Boorman (2003) have also described the application of SWAT to evaluate the impact of climate change on sediments in an agricultural watershed in Minnesota and in five European catchments.

The main objective of this paper is to evaluate the impact of possible future climate on the sediment yield in the Nam Ou River basin in Lao PDR - one of the important subbasins of the Mekong River basin. Studies by Roberts (2001) and Mekong River Commission (2003) concluded that Upper Mekong contributes $50 \%$ of the total annual sediment load of the Lower Mekong River. In the Lower Mekong, the major sediment-contributing source area is located in northern Laos (Lu, 1998), which includes the Nam Ou basin. Fuchs (2004) ranked different catchments in Lower Mekong Basin regarding risk of soil erosion, where the Nam Ou basin is at high risk of soil erosion. Besides, there are extensive plans to build reservoirs in the tributaries within Lao PDR, Vietnam and Cambodia. Under the 20-yr hydropower development plan in tributaries by Mekong River Commission, a total of $4661 \mathrm{MW}$ are expected from Lao tributaries. Out of the above-mentioned power, about $21 \%$ is planned to be generated from Nam Ou with seven cascade dams with total live storage capacity of 1659.4 MCM (Hoanh et al., 2010). In this study, we have attempted to simulate the sediment yield from the Nam Ou basin and to quantify the implications of climate change on sediment load using the SWAT model.

The better quantitative understanding of potential changes due to climate change is complicated by several sources of uncertainty linked to climate change (Minville et al., 2008). 
The uncertainty depends on both climate data and simulated hydrologic regimes (Prudhomme et al., 2003). Climatic uncertainty is linked to greenhouse gas emission scenarios (GHGES) and especially to general circulation models (GCMs), whose representation of topography and climate processes is imperfect, in large part due to computational limitations (Minville et al., 2008). As a number of researchers (e.g., Minville et al., 2008; Kingston et al., 2011) have pointed out that there is a large uncertainty in the results of different GCM models, a multi-model approach is advised. Several authors (e.g Maurer, 2007) have addressed the future climate uncertainty into hydrology impact studies by using multiple GHGES and GCMs. In most studies, GCMs tend to dominate the uncertainties compared to the downscaling methods or the impact models (Di Baldassarre et al., 2012; Elshamy et al., 2012). In this study we have used three GHGES and four GCMs and a RCM (regional climate model) to provide a range of possible future climatic conditions and their impact on sediment yield of the basin. The future temperature and precipitation time series are obtained by applying the change factor or delta change method (Hay et al., 2000) to climate model (GCMs/RCM) simulated temperature and precipitation. Readers should refer to Sect. 3.2 for details on the reasons behind using the GCM/RCM for this study.

\section{Study area}

The Nam Ou River basin, a sub-basin of the Mekong River basin, is located in the northern part of the Lao People's Democratic Republic (Fig. 1). It lies within $21^{\circ} 17^{\prime} 17^{\prime \prime}-$ $22^{\circ} 30^{\prime} 40^{\prime \prime} \mathrm{N}$ and $101^{\circ} 45^{\prime} 47^{\prime \prime}-103^{\circ} 11^{\prime} 57^{\prime \prime} \mathrm{E}$ and covers a total area of $26180.50 \mathrm{~km}^{2}$. The topography of the basin is mostly mountainous, dominated by sharp relief. The elevation of the basin ranges from 263 to $2035 \mathrm{~m}$ above the mean sea level. The climate in the study area is characterized by two distinct seasons: a wet season (May to October) and a dry season (November to April). The mean annual temperature ranges from 20 to $26^{\circ} \mathrm{C}$. The basin receives about $1700 \mathrm{~mm}$ rainfall annually, of which about $80 \%$ falls during the wet season. Woods and shrubland are the dominant land cover in the basin and cover nearly $62 \%$ of the total area. Soil in this river basin is predominantly sandy clay loam. The soil type distribution is shown in Fig. 2, and the properties of the soils are presented in Table 1.

\section{Data and methods}

\subsection{Observed data}

Observed daily rainfall data from eleven stations (Luang Prabang, Xieng Ngeun, Muong Ngoy, Oudomxay, Muong Namtha, Phongsaly, Dien Bien, Lai Chau, Muong Te, Quynh Nhai, and Tuan Giao), and climatic data of daily temperature,

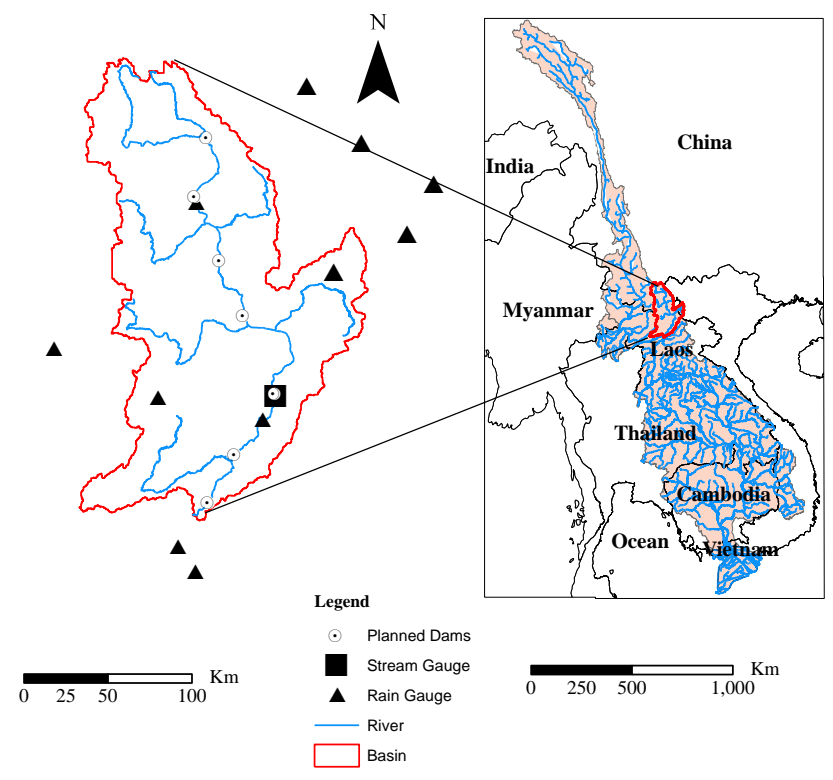

Fig. 1. Location of the study area, stream gauge, rainfall gauges used for interpolating spatial rainfall and location of planned dams.

wind speed, humidity and solar radiation from three stations (Luang Prabang, Oudomxay and Phongsaly) are used for this study. The records for rainfall data are from 1980 2003 , and for other climatic data the period is of $12 \mathrm{yr}$ (19922003). The observed precipitation data at the stations are interpolated and aggregated to the sub-basin by using the MQUAD program in the Decision Support Framework of the Mekong River Commission (MRC). MQUAD is based on multiquadric analysis developed by Hardy (1971). The multiquadric analysis is a mathematical surface fitting technique that has been used extensively for describing geological surfaces (Shaw and Lynn, 1972). In MQUAD the surface is represented as summation of many individual quadric surfaces. For observed rainfall data from an irregular network of rain gauge stations, the multi-quadric analysis is a practicable and efficient method for determining areal rainfall (Shaw and Lynn, 1972). MQUAD generates estimations of areal rainfall. It does this by calculating a multiquadratic surface from available point rain gauge data, such that the surface passes through all gauge points. The surface is defined for a user-specified area, consisting of one or more catchments, and is made up from a grid of estimated point rainfall values calculated by the program. The point values calculated are also aggregated to produce a mean rainfall depth for each catchment. The theory on MQUAD method and its advantage over other methods are described in more detail by Shaw and Lynn (1972).

For calibration of the SWAT model, observed rainfall and temperature data for the period of 1992-2003 are used. The observed data period used for the delta change approach is from 1981-2000 for both temperature and precipitation (see 
Table 1. Major soil types and their properties in the Nam Ou basin (the values in the table are based on soil map used in the SWAT model of the whole Mekong Basin developed by Mekong River Commission).

\begin{tabular}{|c|c|c|c|c|c|c|c|c|}
\hline \multirow[b]{2}{*}{ Soil Name } & \multirow{2}{*}{$\begin{array}{r}\text { Depth of } \\
\text { Soil Layer } \\
(\mathrm{mm})\end{array}$} & \multirow[b]{2}{*}{ Texture } & \multicolumn{3}{|c|}{ Composition (\%) } & \multirow{2}{*}{$\begin{array}{r}\text { Bulk Density } \\
\qquad\left(\mathrm{g} \mathrm{cm}^{-3}\right)\end{array}$} & \multirow{2}{*}{$\begin{array}{r}\text { Available } \\
\text { Water } \\
\text { Capacity } \\
\left(\mathrm{mm} \mathrm{mm}^{-1}\right)\end{array}$} & \multirow{2}{*}{$\begin{array}{r}\text { Saturated } \\
\text { Hydraulic } \\
\text { Conductivity } \\
\left(\mathrm{mm} \mathrm{h}^{-1}\right)\end{array}$} \\
\hline & & & Clay & Silt & Sand & & & \\
\hline \multirow[t]{4}{*}{$\mathrm{ACh}$} & 0-300 & Sandy Clay Loam & 21 & 24 & 55 & 1.46 & 0.23 & 6.50 \\
\hline & $300-600$ & Sandy Clay Loam & 28 & 23 & 50 & 1.46 & 0.22 & 3.49 \\
\hline & $600-1000$ & Sandy Clay Loam & 32 & 20 & 48 & 1.48 & 0.19 & 2.56 \\
\hline & 1000-2000 & Sandy Clay Loam & 30 & 18 & 52 & 1.44 & 0.16 & 2.90 \\
\hline \multirow[t]{4}{*}{$\mathrm{ACh} / \mathrm{CMd}$} & 0-300 & Sandy Clay Loam & 21 & 24 & 55 & 1.46 & 0.23 & 6.50 \\
\hline & $300-600$ & Sandy Clay Loam & 28 & 23 & 50 & 1.46 & 0.22 & 3.49 \\
\hline & $600-1000$ & Sandy Clay Loam & 32 & 20 & 48 & 1.48 & 0.19 & 2.56 \\
\hline & $1000-2000$ & Sandy Clay Loam & 30 & 18 & 52 & 1.44 & 0.16 & 2.90 \\
\hline \multirow[t]{4}{*}{ ACh-C } & $0-300$ & Sandy Clay Loam & 21 & 24 & 55 & 1.46 & 0.23 & 6.50 \\
\hline & $300-600$ & Sandy Clay Loam & 28 & 23 & 50 & 1.46 & 0.22 & 3.49 \\
\hline & $600-1000$ & Sandy Clay Loam & 32 & 20 & 48 & 1.48 & 0.19 & 2.56 \\
\hline & 1000-2000 & Sandy Clay Loam & 30 & 18 & 52 & 1.44 & 0.16 & 2.90 \\
\hline \multirow[t]{4}{*}{$\mathrm{ACh}-\mathrm{C} / \mathrm{ACu}-\mathrm{C}$} & $0-300$ & Sandy Clay Loam & 21 & 24 & 55 & 1.46 & 0.23 & 6.50 \\
\hline & $300-600$ & Sandy Clay Loam & 28 & 23 & 50 & 1.46 & 0.22 & 3.49 \\
\hline & $600-1000$ & Sandy Clay Loam & 32 & 20 & 48 & 1.48 & 0.19 & 2.56 \\
\hline & $1000-2000$ & Sandy Clay Loam & 30 & 18 & 52 & 1.44 & 0.16 & 2.90 \\
\hline \multirow[t]{4}{*}{ ACh-C/LPd } & $0-300$ & Sandy Clay Loam & 21 & 24 & 55 & 1.46 & 0.23 & 6.50 \\
\hline & $300-600$ & Sandy Clay Loam & 28 & 23 & 50 & 1.46 & 0.22 & 3.49 \\
\hline & $600-1000$ & Sandy Clay Loam & 32 & 20 & 48 & 1.48 & 0.19 & 2.56 \\
\hline & $1000-2000$ & Sandy Clay Loam & 30 & 18 & 52 & 1.44 & 0.16 & 2.90 \\
\hline \multirow[t]{4}{*}{ CMd } & $0-300$ & Clay Loam & 31 & 33 & 37 & 1.23 & 0.24 & 3.39 \\
\hline & $300-600$ & Clay Loam & 30 & 27 & 44 & 1.23 & 0.22 & 3.36 \\
\hline & $600-1000$ & Sandy Clay Loam & 27 & 26 & 48 & 1.24 & 0.22 & 4.12 \\
\hline & 1000-2000 & Loam & 26 & 28 & 46 & 1.28 & 0.1 & 4.47 \\
\hline \multirow[t]{4}{*}{$\mathrm{CMd} / \mathrm{ACh}$} & 0-300 & Clay Loam & 31 & 33 & 37 & 1.23 & 0.24 & 3.39 \\
\hline & $300-600$ & Clay Loam & 30 & 27 & 44 & 1.23 & 0.22 & 3.36 \\
\hline & $600-1000$ & Sandy Clay Loam & 27 & 26 & 48 & 1.24 & 0.22 & 4.12 \\
\hline & 1000-2000 & Loam & 26 & 28 & 46 & 1.28 & 0.1 & 4.47 \\
\hline \multirow[t]{4}{*}{$\mathrm{CMe}$} & 0-300 & Loam & 27 & 34 & 39 & 1.49 & 0.22 & 4.42 \\
\hline & $300-600$ & Loam & 26 & 32 & 42 & 1.53 & 0.2 & 4.65 \\
\hline & $600-1000$ & Loam & 26 & 29 & 45 & 1.55 & 0.19 & 4.48 \\
\hline & 1000-2000 & Loam & 26 & 33 & 41 & 1.49 & 0.13 & 4.76 \\
\hline
\end{tabular}

Sect. 3.2.2 for details). While the observed rainfall data were available for 1980-2003 (covering the entire 20-yr period used), the temperature data were available for 1992-2003 period only. Therefore, daily maximum and minimum temperatures for 1980-1991 are derived from the 0.5-degree gridded global observed daily maximum and minimum temperature data (from Adam and Lettenmaier, 2003, as modified in Central America per Maurer et al., 2009), which are available for 1950 through 1999 from the Santa Clara University (SCU). Details of the SCU data can be found in Maurer et al. (2009). These data are downloaded through the following link: http: //www.engr.scu.edu/ emaurer/global_data/. The statistics of the observed maximum and minimum monthly temperatures for three stations of the sub-basin are compared with the SCU data for the years 1992-1999, as given in Table 2. The comparison shows a good relationship between the observed and SCU data, with $R^{2}$ of 0.8 and above, and almost similar standard deviation. Table 2 also presents the linear relationships between the observed and SCU data at various stations. These relationships (i.e., the correlations obtained from the monthly temperature data for the period 1992-1999) are used to derive missing daily temperature data for the stations from the SCU gridded data for the period 1980-1991. The monthly values are used, because direct comparison of the 


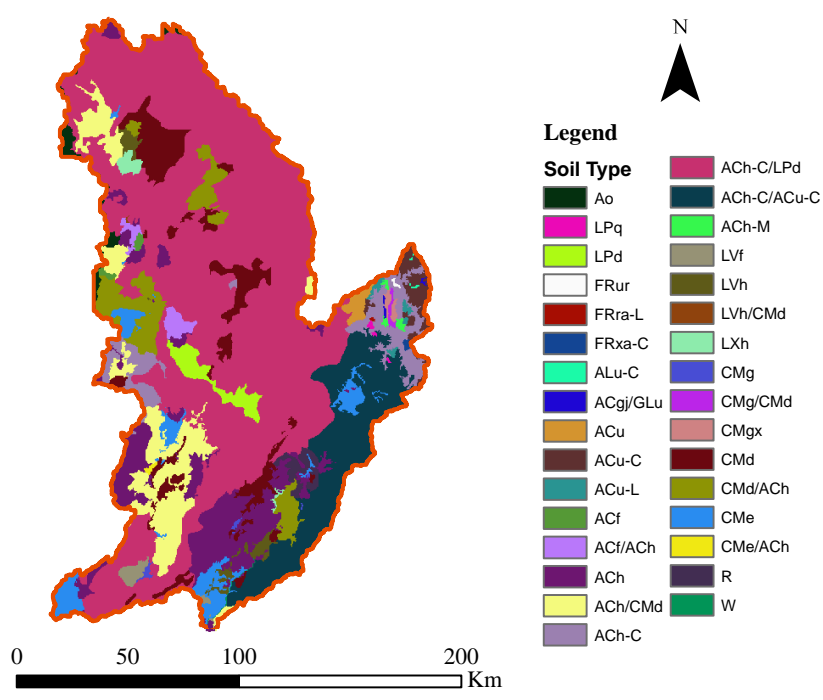

Fig. 2. Soil type distribution map of the Nam Ou basin. For details of soil type, refer to Table 1 .

daily data did not show good correlation. This also motivated the sensitivity analysis in order to check if errors in the temperature records have an influence on the simulation results. The difference between the mean observed temperature (station) and the SCU temperature (grid) is particularly high for the Luang Prabang station (Table 2), i.e., mean absolute differences of $3.7^{\circ} \mathrm{C}(12 \%$ of the observed) in the maximum temperature and $2.8^{\circ} \mathrm{C}(14 \%$ of the observed $)$ in the maximum temperature. Overall the differences are well within $\pm 15 \%$. For remaining stations the differences are within $\pm 5 \%$ (Oudomxay) and $\pm 10 \%$ (Phongsaly). A sensitivity analysis of the discharge and sediment yield simulations (for the period 1980-1991) with respect to the change in temperature is carried out at all three stations applying respective percent change in the daily temperature derived from the SCU data. The results showed nominal impact of the applied errors on the temperature to the discharge as well as the sediment yield (Fig. 3). In general, the impact on the sediment yield is relatively larger than on the discharge. This might be due to the plant growth module of SWAT where plant development is based on accumulated heat units. In accumulated head units, temperature is the most important factor governing the plant growth. In general higher temperature (within the maximum favorable limit) gives rise to the rapid growth of plant resulting in less erosion. On the other hand, decrease in temperature inhibits plant growth resulting in more erosion.

The meteorological data, daily discharge (for 1992-2003) and suspended sediment concentration (SSC) data (for 19962002) from the gauging station at Muong Ngoy in the study area are obtained from the MRC Secretariat, Phnom Penh, Cambodia. Unlike discharge, measurements of SSC were sporadic, ranging from 6 to 56 measurements per year.
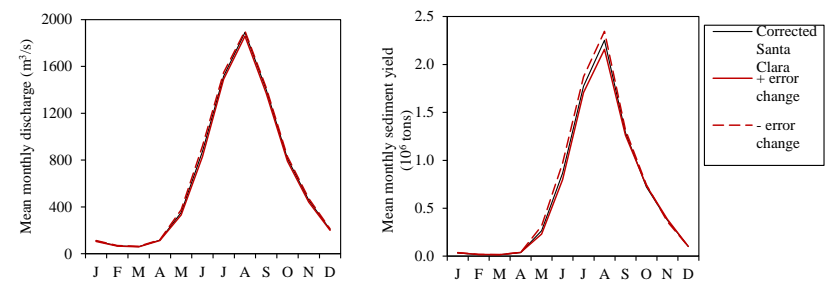

Fig. 3. Sensitivity of the discharge (left) and sediment yield (right) simulations on Tmax and Tmin for 1980-1991.

\subsection{Future climate simulations}

\subsubsection{General circulation models}

For this study four GCMs are selected on the basis of their performance in the simulation of precipitation in the 20th century in the Southeast Asia region as found in the literature (Easthma et al., 2008, and Cai et al., 2009). For the selected GCMs all available scenarios are taken (Table 3), which is in all cases the A2 $(870 \mathrm{ppm}$ of GHG at the end of 21 st century), A1b (GHG of $720 \mathrm{ppm}$ stabilization) and B1 scenario (GHG of $550 \mathrm{ppm}$ stabilization) (IPCC, 2007). The selected GCMs are downloaded from the WCRP CMIP3 multi-model database data portal, which is available at https: //esg.llnl.gov.8433/home/publicHomePage.do. Monthly average surface temperature and monthly total precipitation output covering the 20th and 21st century are used for the downscaling. The models have various spatial resolutions, varying between $1.4^{\circ}$ to about $3.75^{\circ}$ grid cells.

\subsubsection{Regional climate model outputs}

The RCM used in this study is PRECIS, developed by the Hadley Centre of the UK Meteorological Office. The PRECIS RCM is based on the atmospheric components of the ECHAM4 GCM from the Max Planck Institute for Meteorology, Germany. The PRECIS data are produced by the Southeast Asian System for Analysis, Research and Training (START) Regional Center for 2225 grid cells covering the entire Mekong River basin with the resolution of $0.2 \times 0.2$ degree (approximately $22 \times 22 \mathrm{~km}^{2}$ ). These data, comprising two data sets for ECHAM4 SRES A2 and B2, include daily precipitation and maximum and minimum daily temperatures. The PRECIS RCM data over the periods of 1971-2000 (present) and 2011-2070 (future), for both A2 and B2 scenarios, are obtained from the Southeast Asian START Regional Center website http://www.start.or.th/. The specific boundary for the Nam Ou basin lies between latitudes $19.46^{\circ}-22.77^{\circ} \mathrm{N}$ and longitudes $100.72^{\circ}-103.32^{\circ} \mathrm{E}$. The RCM with two scenarios (A2 and B2) is used for this study, because it is being used by Mekong River Commission for climate change studies and this RCM covers the entire Mekong River basin. 
Table 2. Comparison of and relationship between observed and Santa Clara University (SCU) gridded observed monthly temperature data for the 1992-1999 period.

\begin{tabular}{|c|c|c|c|c|c|c|c|}
\hline \multirow[b]{2}{*}{ Station } & \multirow[b]{2}{*}{$R^{2}$} & \multirow{2}{*}{$\begin{array}{l}\text { Standard } \\
\text { Error }\end{array}$} & \multicolumn{2}{|c|}{ Mean } & \multicolumn{2}{|c|}{ Standard Deviation } & \multirow{2}{*}{$\begin{array}{l}\text { Relationship between monthly observed } \\
\text { and Santa Clara gridded observed data }\end{array}$} \\
\hline & & & Observed & Santa Clara & Observed & Santa Clara & \\
\hline \multicolumn{8}{|c|}{$T_{\max }\left({ }^{\circ} \mathrm{C}\right)$} \\
\hline Luang Prabang & 0.8 & 1.3 & 31.3 & 27.6 & 3.0 & 2.3 & Obs. $T_{\max }=1.1596 \mathrm{SCU} T_{\max }-0.6673$ \\
\hline Oudomxay & 0.9 & 0.9 & 28.8 & 27.3 & 2.6 & 2.5 & Obs. $T_{\max }=0.9657 \mathrm{SCU} T_{\max }+2.4270$ \\
\hline Phongsaly & 0.8 & 1.3 & 23.7 & 26.1 & 3.0 & 2.9 & Obs. $T_{\max }=0.9597 \mathrm{SCU} T_{\max }-1.4027$ \\
\hline \multicolumn{8}{|c|}{$T_{\min }\left({ }^{\circ} \mathrm{C}\right)$} \\
\hline Luang Prabang & 0.8 & 1.7 & 20.0 & 17.2 & 3.9 & 3.7 & Obs. $T_{\min }=0.9679 \mathrm{SCU} T_{\min }+3.3511$ \\
\hline Oudomxay & 0.9 & 1.1 & 17.0 & 17.0 & 4.7 & 3.9 & Obs. $T_{\min }=1.1793 \mathrm{SCU} T_{\min }-3.0752$ \\
\hline Phongsaly & 0.8 & 1.3 & 16.2 & 16.2 & 2.9 & 4.1 & Obs. $T_{\min }=0.6526 \mathrm{SCU} T_{\min }+5.549$ \\
\hline
\end{tabular}

Table 3. GCMs downscaled for this study.

\begin{tabular}{lll}
\hline GCM & Emission scenario & Spatial resolution \\
\hline CCCMA CGCM3.1 & A2, A1b, B1 & $48 \times 96$ cells, $3.75^{\circ} \times 3.75^{\circ}$ \\
CNRM-CM3 & A2, A1b, B1 & $64 \times 128$ cells, $2.8^{\circ} \times 2.8^{\circ}$ \\
MPI ECHAM5 & A2, A1b, B1 & $96 \times 192$ cells, $1.9^{\circ} \times 1.9^{\circ}$ \\
NCAR CCSM3 & A2, A1b, B1 & $128 \times 256$ cells, $1.4^{\circ} \times 1.4^{\circ}$ \\
\hline
\end{tabular}

Note: CCCMA CGCM 3.1 stands for Canadian Centre for Climate Modelling and Analysis Coupled Global Climate Model, version 3.1; CNRM-CM3 stands for Centre National de Recherches Meteorologiques Climate Model, version 3; MPI ECHAM stands for Max Planck Institute for Meteorology fifth-generation atmospheric general circulation model and NCAR CCSM3 stands for National Center for Atmospheric Research Community Climate System Model, version 3.0 (source: http://www.ipcc-data.org/ar4/gcm_data.html, last accessed on 13 November 2012)

Several statistical downscaling techniques have been developed to translate large-scale GCM/RCM output into finer resolution (Fowler et al., 2007). In this study, the simplest method - change factor or delta change approach - has been applied. The change factor or delta change method has been used in many climate change impact studies earlier (Hay et al., 2000; Diaz-Nieto and Wilby, 2005; Akhtar et al., 2008; Minville et al., 2008; Chen et al., 2011). Basically, this approach modifies the observed daily temperature by adding the difference between the monthly future and historic temperatures as simulated by the GCM or RCM for each time period. Similarly, the observed historical time series of precipitation is modified by multiplying the ratio of the monthly future and historic precipitations simulated by a GCM or RCM for each time period. The observational database used for this approach covers the period of 1981-2000 for both temperature and precipitation in this study.

\subsection{SWAT model description}

SWAT is a river basin- or watershed-scale, semi-distributed, process-based, and continuous time hydrologic and water quality model initially developed by Arnold et al. (1993) and designed to evaluate the effect of land use management on water, sedimentation, and agricultural chemical yields in large complex watersheds that are heterogeneous in land use, soil and management conditions over a long period of time (Arnold et al., 1998; Neitsch et al., 2005). SWAT subdivides a watershed into different sub-basins connected by a stream network, and further into hydrological response units (HRUs). HRUs are the lumped land areas within the subbasin that are comprised of unique land cover, soil, slope and management combinations. SWAT simulates the hydrology of the watershed in two phases. The land phase of the hydrologic cycle controls the amount of water, sediment, nutrient and pesticide loadings to the main channel in each subbasin. The water or routing phase of the hydrologic cycle controls the movement of water, sediment, nutrients and pesticide loadings through the channel network of the watershed into the outlet.

SWAT estimates the surface runoff volume from HRUs using the SCS (Soil Conservation Service) curve number method (USDA-SCS, 1972) or the Green and Ampt infiltration method (Green and Ampt, 1911). In this study, the SCS curve number method has been used, which is a function of the soil's permeability, land use and antecedent soil water conditions as defined in SWAT. SCS defines three antecedent moisture conditions: dryness (wilting point), average moisture, and wetness (field capacity). SWAT calculates the peak runoff rate with a modified rational method. The model offers three options for estimating potential evapotranspiration: the Hargreaves (Hargreaves et al., 1985), PriestleyTaylor (Priestley and Taylor, 1972), and Penman-Monteith (Monteith, 1965) methods. The Penman-Monteith method has been used in this study. The model calculates the surface erosion within each HRU with the modified universal soil loss equation (MUSCLE) (Williams, 1975). The MUSCLE is

$$
\begin{aligned}
\text { sed } & =11.8 \times\left(Q_{\text {surf }} \times q_{\text {peak }} \times \text { area }_{\mathrm{hru}}\right)^{0.56} \\
& \times K_{\mathrm{USLE}} \times C_{\mathrm{USLE}} \times P_{\mathrm{USLE}} \times \mathrm{LS}_{\mathrm{USLE}} \times \mathrm{CFRG}
\end{aligned}
$$

where sed is the sediment yield (metric t day ${ }^{-1}$ ), $Q_{\text {surf }}$ is the surface runoff volume $\left(\mathrm{mm} \mathrm{ha}^{-1} \mathrm{day}^{-1}\right), q_{\text {peak }}$ is the peak 
runoff rate $\left(\mathrm{m}^{3} \mathrm{~s}^{-1}\right)$, areahru is the area of the HRU (ha), $K_{\text {USLE }}$ is the USLE (Universal Soil Loss Equation) soil erodibility factor, $C_{\mathrm{USLE}}$ is the USLE cover and management factor, $P_{\text {USLE }}$ is the USLE support practice factor, LS $_{\text {USLE }}$ is the USLE topographic factor and CFRG is the coarse fragment factor. These parameters are estimated in calibration.

SWAT uses Manning's equation to define flow rate and velocity. Water is routed through the channel network using the variable storage routing method developed by Williams (1969) or the Muskingum routing methods, which are variations of the kinematic wave model. For this study, the variable storage routing method is used. The sedimentrouting model (Arnold et al., 1995) that simulates sediment transport in the channel network consists of two components operating simultaneously: deposition and degradation. The amount of deposition and degradation is based on the maximum concentration of sediment in the reach and the concentration of sediment in the reach at the beginning of the time step. The final amount of sediment in the reach is determined as

$\operatorname{sed}_{\mathrm{ch}}=\operatorname{sed}_{\mathrm{ch}, i}-\operatorname{sed}_{\mathrm{dep}}+\operatorname{sed}_{\mathrm{deg}}$

where $\operatorname{sed}_{\mathrm{ch}}$ is the amount of suspended sediment in the reach (metric $\mathrm{tday}^{-1}$ ), $\mathrm{sed}_{\mathrm{ch}, i}$ is the amount of suspended sediment in the reach at the beginning of the time period (metric $\left.\mathrm{tday}^{-1}\right), \mathrm{sed}_{\mathrm{dep}}$ is the amount of sediment deposited in the reach segment (metric tday ${ }^{-1}$ ), and $\operatorname{sed}_{\mathrm{deg}}$ is the amount of sediment re-entrained in the reach segment (metric tday ${ }^{-1}$ ).

The amount of sediment transported out of the reach is calculated as

$\operatorname{sed}_{\text {out }}=\operatorname{sed}_{\mathrm{ch}} \times \frac{V_{\text {out }}}{V_{\text {ch }}}$

where $\operatorname{sed}_{\text {out }}$ is the amount of sediment transported out of the reach $\left(\right.$ metric t day $\left.^{-1}\right), \mathrm{sed}_{\mathrm{ch}}$ is the amount of suspended sediment in the reach (metric tday ${ }^{-1}$ ), $V_{\text {out }}$ is the volume of outflow during the time step $\left(\mathrm{m}^{3} \mathrm{day}^{-1}\right)$, and $V_{\mathrm{ch}}$ is the volume of water in the reach segment $\left(\mathrm{m}^{3} \mathrm{day}^{-1}\right)$.

SWAT simulates plant growth based on daily accumulated heat units where temperature is one of the most important factors governing plant growth. Each plant has its own temperature range, i.e., its minimum, optimum and maximum for growth. For any plant, a minimum or base temperature must be reached before any growth will take place. Above the base temperature, the higher the temperature the more rapid is the growth rate of the plant. Once the optimum temperature is exceeded, the growth rate will begin to slow until a maximum temperature is reached, at which growth ceases. Actual growth varies from potential growth due to extreme temperatures, water deficiencies and nutrient deficiencies. Plant growth may be reduced due to extreme temperature, insufficient water, nitrogen or phosphorus. The amount of stress for each of these four parameters is calculated by SWAT on a daily basis. The detailed descriptions of the different model components can be found in Neitsch et al. (2005).
The main input data for the SWAT model consist of daily precipitation, maximum and minimum air temperatures, wind speed, humidity, solar radiation, and spatial data on digital elevation model (DEM), land use and soil. River discharge and suspended sediment yield are used for calibration and validation purposes. The input datasets for the model are obtained from the MRC Secretariat, Phnom Penh, Cambodia. In this study, a 250-m resolution DEM is used to delineate watershed and sub-basin boundaries, and to calculate sub-basin average slopes and to outline the stream network. The DEM used for this study is based on interpolated topographic maps. Land use specifications, soil and slope layers are used to create HRUs within each sub-basin area.

\subsubsection{Model calibration and validation}

The Nam Ou SWAT model is calibrated and validated for streamflow but only calibrated for sediment yield. The periods 1992-1999 and 2000-2003 are used for streamflow calibration and validation respectively, including $2 \mathrm{yr}$ as a warmup period. The warm-up period allows the model to cycle multiple times so as to minimize the effect of the user's estimates of initial state variables such as soil and water content and surface residue (Zhang et al., 2007). For this study, the sediment load is only calibrated for 1996-2002 due to the sporadic nature of data (only 176 measurements in $7 \mathrm{yr}$ ). For streamflow, the calibration is carried out both manually and automatically, while for sediment only manual calibration is performed. The SWAT-CUP software (Abbaspour, 2008) is used for the automatic calibration of the SWAT model. The sequential uncertainty fitting (SUFI-2) algorithm (Abbaspour et al., 2004, 2007) is used for the parameter optimization. SUFI-2 enables sensitivity analysis, calibration, validation, and uncertainty analysis of SWAT models. A number of successful applications of the method have been reported in the literature including Masih et al. (2011a, b). This procedure is known to produce comparable results with widely used auto-calibration methods (Yang et al., 2008). In SUFI-2, in order to run an automatic calibration, the parameters that are to be calibrated (most sensitive ones) and their initial values and ranges need to be specified. In order to specify more realistic initial values and ranges to the parameters, a manual calibration is used. So, the calibration procedure applied in this study is like a pre-calibration or rough calibration manually followed by further refinement through the SUFI-2 automatic procedure. For the case of sediment, the automatic calibration could not improve the overall performance obtained by the manual calibration. In SUFI-2 there are two ways to change parameter values during calibration: one by directly changing the absolute value of the parameter, and another by changing the parameter value relative to the initial value specified for the parameter. Readers are referred to Abbaspour et al. (2007) for the details of SUFI-2 procedure. However the short description on algorithm of SUFI-2 is presented in Sect. 3.3.2. 
The calibrations for the stream flow and sediment yield are carried out separately, because in SWAT it is common practice to calibrate the stream flow before calibrating for sediment yield. Some of the parameters (e.g., the curve number) of stream flow also influence the sediment yield. Therefore, while calibrating sediment, the parameters that influence the sediment yield but not the stream flow are calibrated. It is worth mentioning here that for model calibration and validation interpolated observed rainfall is used.

\subsubsection{Model evaluation and uncertainty analysis}

The model performance is evaluated using the coefficient of determinant $\left(R^{2}\right)$, the Nash-Sutcliffe (NS) measure (Nash and Sutcliffe, 1970) and percent bias (PBIAS). Several researchers (such as Santhi et al., 2001; Benaman et al., 2005) have suggested that the prediction efficiency of a calibrated model can be judged as satisfactory if NS and $R^{2}$ values are $>0.6$ for mean behavior (Setegn et al., 2010). A PBIAS value $<15 \%$ is considered to be a satisfactory performance rating of a calibrated model by a number of researchers (Santhi et al., 2001; Van Liew et al., 2007).

SUFI-2 is used for the uncertainty analysis of the SWAT model. In SUFI-2, parameter uncertainty accounts for all sources of uncertainties such as uncertainty in driving variables (e.g., rainfall), conceptual model, parameters, and measured data. Uncertainty of input parameters is depicted as uniform distributions, while model output uncertainty is quantified by the $95 \%$ prediction uncertainty (95PPU) calculated at the $2.5 \%$ and $97.5 \%$ levels of the cumulative distribution of output variables obtained through Latin hypercube sampling (Abbaspour et al., 2007). SUFI-2 starts by assuming a large parameter uncertainty, so that the measured data initially fall within the 95PPU, then decrease this uncertainty in steps until two rules are satisfied: (1) the 95PPU band brackets "most of the observations", and (2) the average distance between the upper (at 97.5\% level) and the lower (at $2.5 \%$ level) parts of the 95PPU is "small" (Abbaspour et al., 2007). Similarly to GLUE, SUFI-2 represents uncertainties of all sources through parameter uncertainty in the hydrological model (Yang et al., 2008). A short step-by-step description of SUFI-2 optimizing algorithm as described in Yang et al. (2008) is as follows:

Step 1. An objective function $g(b)$ is defined. A number of alternative objective functions are available, e.g., the sum of squares, $R^{2}, \mathrm{NS}$, etc. In this study we chose the NS coefficient (maximize) for the objective function.

Step 2. Meaningful absolute minimum and maximum ranges $\left[b_{\text {absmin }}, b_{\text {absmax }}\right]$ for the parameters being optimized are defined.

Step 3. Latin hypercube sampling is carried out in the hypercube $\left[b_{\min }, b_{\max }\right]$ (initially set to $\left[b_{\text {absmin }}\right.$, $\left.b_{\text {absmax }}\right]$ ), the corresponding objective functions are evaluated, and the sensitivity matrix $\mathbf{J}$ and the parameter covariance matrix $\mathbf{C}$ are calculated according to

$$
\begin{aligned}
& \mathbf{J}_{i j}=\frac{\Delta g_{i}}{\Delta b_{j}}, i=1, \ldots, \mathbf{C}_{2}^{n}, j=1, \ldots, m, \\
& \mathbf{C}=S_{g}^{2}\left(\mathbf{J}^{T} \mathbf{J}\right)^{-1}
\end{aligned}
$$

where $S_{g}^{2}$ is the variance of the objective function values resulting from the $m$ model runs.

Step 4. A $95 \%$ predictive interval of a parameter $b_{j}$ is computed as follows:

$$
\begin{aligned}
b_{j, \text { lower }} & =b_{j}^{*}-t_{v, 0.025} \sqrt{\mathbf{C}_{j j}}, b_{j, \text { upper }} \\
& =b_{j}^{*}+t_{v, 0.025} \sqrt{\mathbf{C}_{j j}}
\end{aligned}
$$

where $b_{j}^{*}$ is the parameter $b_{j}$ for the best estimates (i.e., parameters that produce the optimal objective function), and $m$ is the degrees of freedom $(m-n)$.

Step 5. The 95PPU is calculated. And then the two indices, i.e., the $p$-factor (the percent of observations bracketed by the 95PPU) and the $r$-factor, are calculated:

$$
\begin{aligned}
& \bar{d}_{x}=\frac{1}{k} \sum_{t=1}^{k}\left(X_{U}-X_{L}\right)_{l} \\
& r \text {-factor }=\frac{\bar{d}_{x}}{\sigma_{x}}
\end{aligned}
$$

where $d_{x}$ is the average distance between the upper and lower 95PPU, $X_{U}$ and $X_{L}$ represent the upper and lower boundaries of the 95PPU, and $\sigma_{x}$ is the standard deviation of the measured data.

The goodness of fit and the degree to which the calibrated model accounts for the uncertainties are assessed by the closeness of the $p$-factor to $100 \%$ (i.e., all observations falling inside the prediction uncertainty band) while having the narrowest band ( $r$-factor $\rightarrow 0$ ). As all uncertainties in the conceptual model and inputs are reflected in the measurements, bracketing most of the measured data in the prediction 95PPU ensures that all uncertainties are depicted by the parameter uncertainties. If the two factors have satisfactory values, then a uniform distribution in the parameter hypercube $\left[b_{\min }, b_{\max }\right]$ is interpreted as the posterior parameter distribution. Otherwise, $\left[b_{\min }, b_{\max }\right]$ is updated according to

$b_{j, \min }^{\prime}=b_{j, \text { lower }}-\max \left(\frac{\left(b_{j, \text { lower }}-\mathrm{b}_{\mathrm{j}, \min }\right)}{2}, \frac{\left(b_{j, \text { max }}-b_{j, \text { upper }}\right)}{2}\right)$,

$b_{j, \max }^{\prime}=b_{j, \text { upper }}+\max \left(\frac{\left(b_{j, \text { lower }}-b_{j, \min }\right)}{2}, \frac{\left(b_{j, \max }-b_{j, \text { upper }}\right)}{2}\right)$,

and another iteration needs to be performed. 

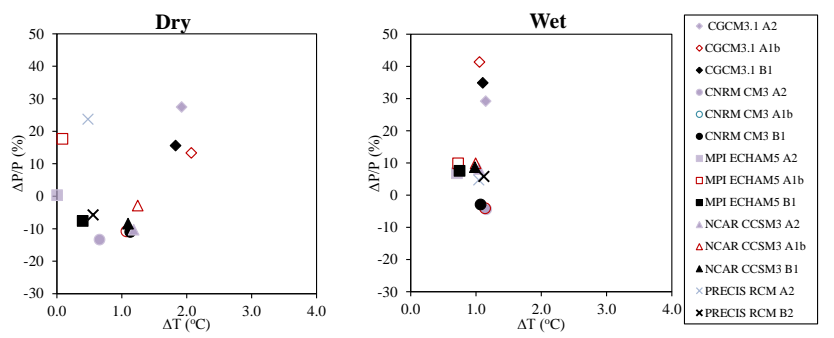

Fig. 4a. Projected changes in seasonal temperature and precipitation for all climate models (GCM/RCM) and GHGES for the period 2011-2040.

\section{Results and discussion}

\subsection{Changes in climate}

\subsubsection{Seasonal}

Projected changes in the seasonal temperature and precipitation are presented in Fig. 4a and $\mathrm{b}$ for all climate projections and two time periods (2011-2040 and 2041-2070). The scatter plots indicate that all projections show an increase in temperature for all chosen periods. The projected seasonal temperature shift varies from $0-2.07^{\circ} \mathrm{C}$ in $2011-2040$ to between $1.26-3.00^{\circ} \mathrm{C}$ in $2041-2070$, depending on the season, GHGES and climate models. In both prediction periods, it can be noted that the temperature increase is larger in the dry season (November-April) than in the wet season (MayOctober). The scatter plot also indicates that the inter-model variability is larger in the dry season.

In case of precipitation, for the wet season (May-October), the GHGES and climate model projections indicate an increase of $41 \%$ for $2011-2040$ and $34 \%$ for $2041-2070$ period. However, a few projections suggest a decreasing trend by as much as $4 \%$ for $2011-2040$ and $8 \%$ for $2041-2070$ period. Similar trends are also projected for the dry seasonal changes. For each time period, the maximum increase in precipitation is projected for the wet season (34-41\%) while the maximum decrease in precipitation is projected for the dry season $(13-27 \%)$. The scatter plots also indicate that for wet season inter-model variability decreases with each time period while for dry season it increases, as shown by the changes in scatter in Fig. 4a and b. The results also clearly indicate that, in general, the variability between climate models for a given scenario is larger than the variability between GHGES for that climate model, which is also noted by Minville et al. (2008).

In general, all projections show an increase in seasonal temperature over the basin. In contrast, projected changes in precipitation are not unidirectional and vary depending on the GHGES, climate models, and time period and on the season.
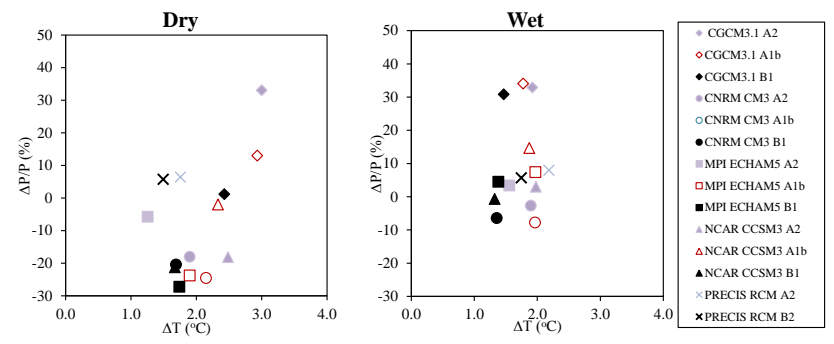

Fig. 4b. Projected changes in seasonal temperature and precipitation for all climate models (GCM/RCM) and GHGES for the period 2041-2070.

\subsubsection{Intra-annual variability}

Figure 5 presents the annual average temperature and precipitation cycle for all climate projections for the 2011-2040, 2041-2070 periods, and for the 1971-2000 base period. It can be seen from the figure that all GHGES and climate model projections indicate an increase in the monthly temperature for all chosen periods except for MPI ECHAM5 GCM where, for 2011-2040, the temperatures of a few months (January, February and November) are projected to decrease ranging from 0.4 to $0.6^{\circ} \mathrm{C}$ depending upon GHGES. For monthly temperature the change ranges between $-0.6-2.5^{\circ} \mathrm{C}$ in $2011-2040$ and $0.4-3.4^{\circ} \mathrm{C}$ in $2041-$ 2070 depending on the GHGES and climate models. This indicates that the variability of change in monthly temperature is greater than the seasonal changes. A variation between GHGES and climate models in the monthly patterns of temperature changes is also observed. For example, in 2011-2040 period under CNRM-CM3 B1 scenario, the maximum change in temperature is projected in May and minimum change in temperature is projected in July. In contrast, under A1B scenario of CNRM-CM3 GCM, the maximum and minimum changes in the temperature are projected for June and September respectively. Also under MPI ECHAM5 Alb scenario, the minimum change is projected for January. In contrast, the maximum change is projected for January in NCAR CCSM3 A1b scenario.

Unlike temperature, the changes in monthly precipitation are not unidirectional for all GHGES, climate models and time period. However, similar to temperature the variation between GHGES and climate models in the monthly patterns of precipitation changes is also observed. The intra-annual patterns of changes range from unimodal (e.g., in 20112040 period precipitation decrease in December-February and increases in March-November: CGCM $3.1 \mathrm{~A} 1 \mathrm{~b}$ scenario) to multi-modal (e.g., in 2041-2070 period precipitation decrease in January, February and March and increases in February-April, June-October and December: CGCM $3.1 \mathrm{~A} 1 \mathrm{~b}$ scenario). For monthly precipitation the changes ranges between $-71-102 \%$ in 2011-2040 and $-80-112 \%$ in 2041-2070 depending on the GHGES and climate models. 

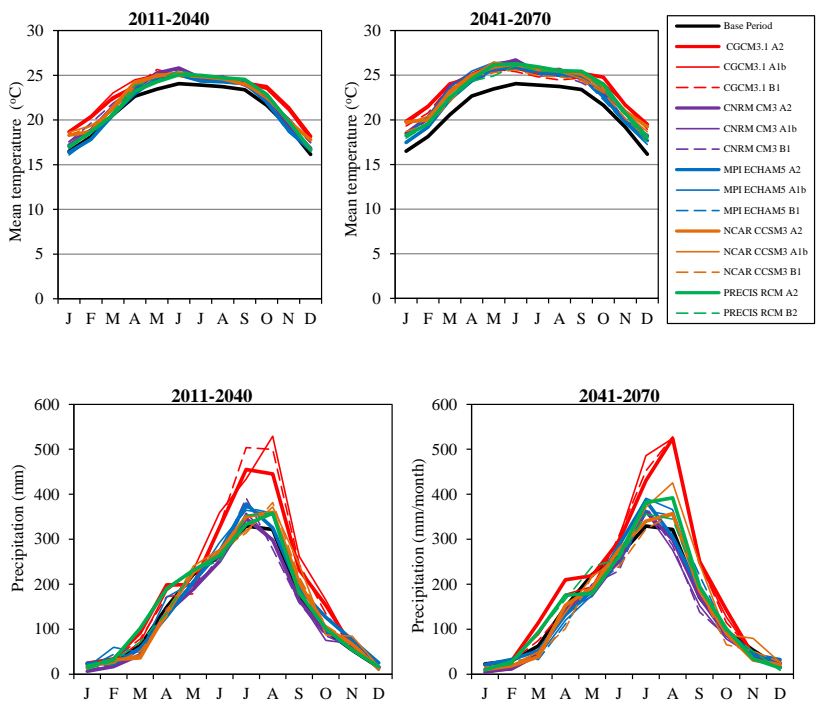

Fig. 5. Monthly temperature and precipitation averaged for all climate projections for the 2011-2040, 2041-2070 periods and for the base period 1971-2000 for the Nam Ou basin.

The change in peak rainfall is also noted for CGCM 3.1, and NCAR CCSM3 GCMs and PRECIS RCM depending upon GHGES and time period. For the above-mentioned scenarios, the peak shifted from July to August (Fig. 5).

\subsubsection{Uncertainty of future average temperature and annual precipitation data}

Figure 6 shows probability density functions (PDFs) of the annual temperature and precipitation, which are built to show the uncertainties related to GHGES and climate models. Normal distribution is fitted to construct the probability density functions (PDFs). It is assumed that each climate projection had an equal probability of occurrence. The PDFs display the range of possible values for each variable and for each time period. The total area under each PDF is equal to 1 . For example, for annual precipitation data representative of the control period (bold black line), expected values are between 600 and $2900 \mathrm{~mm} \mathrm{yr}^{-1}$. The median is $1699 \mathrm{~mm} \mathrm{yr}^{-1}$.

The PDFs indicate that, for both variables, uncertainty increases with time. PDFs also show that all climate models propose an increase in temperature. The magnitude of this change varies in between climate models. The climate change projections from MPI ECHAM 5 show the smallest temperature increases, of about $0.36-1.94^{\circ} \mathrm{C}$ for the $2011-$ 2040 and 2041-2070 periods, while the CGCM 3.1 and NCAR CCSM3 models project an increase of $1.04-2.46^{\circ} \mathrm{C}$ for the same periods. The PRECIS RCM, on the other hand, projected an increase of $0.76-1.97^{\circ} \mathrm{C}$ for $2011-2040$ and 2041-2070. The climate models behave differently for annual precipitation compared to temperature. The PDFs show that some GCMs (CNRM-CM3, MPI ECHAM 5 and NCAR CCSM3) predicted a decrease in precipitation depending on
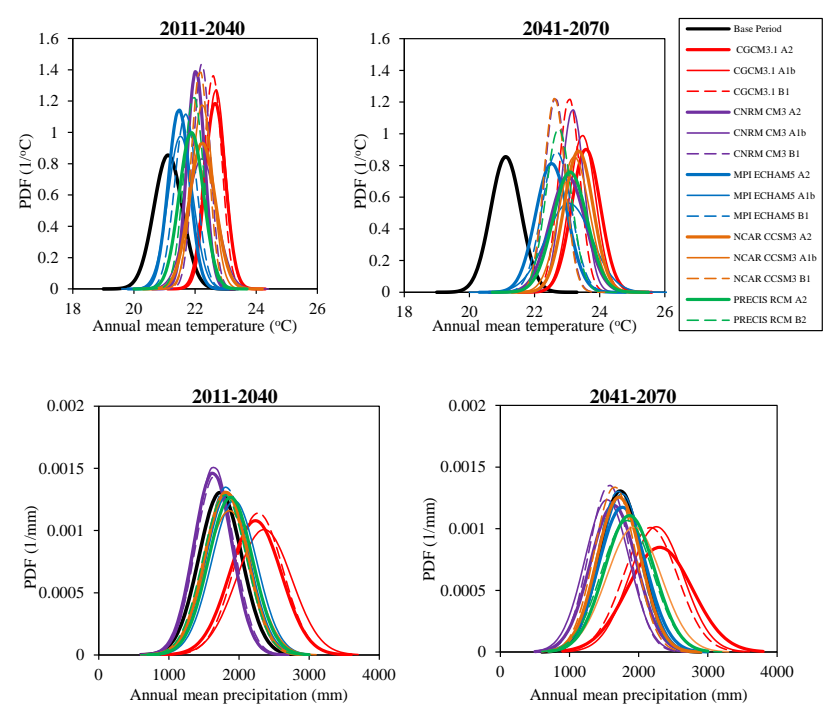

Fig. 6. Probability density functions of annual mean temperature and annual precipitation data for all climate projections, and for the 1971-2000 as base period. PDFs are presented for the 2011-2040 and 2041-2070 time periods.

the time period. The magnitude of increase varies from one model to another ranging from $61.7-623.4 \mathrm{~mm} \mathrm{yr}^{-1}$ in 20112040 and $24.1-570.7 \mathrm{~mm} \mathrm{yr}^{-1}$ in $2041-2070$. CGCM 3.1 GCM predicts the largest increase (32.9-35.9\%) in annual precipitation for both periods. On the other hand, the magnitude in decrease varies between $77.5-190.4 \mathrm{~mm} \mathrm{yr}^{-1}$ for the period of 2011-2070. CNRM-CM3 predicts the largest decrease $(6.1-11 \%)$ in annual precipitation. The PDFs show that future average temperatures and precipitation projected by the different climate models will not be completely distinct of the current natural variability by 2070 , as the spread of PDFs of the control period and in future is similar except for CGCM3.1. The spread of the PDFs based on the CGCM3.1 is relatively wider indicating larger variability.

\subsection{Model calibration and validation}

Table 4 presents the parameters that are used for the model calibration with their calibrated values. The most sensitive parameters for flow predictions are found to be the base flow alpha factor (ALPHA_BF), recharge to deep aquifer (RCHRG_DP), curve number (CN2), channel effective hydraulic conductivity (CH_K2), available water capacity (SOL_AWC), Manning's n-value for the main channel (CH_N2), surface runoff lag time (SURLAG), soil evaporation compensation factor (ESCO), saturated hydraulic conductivity (SOL_K), groundwater delay time (GW_DELAY) and canopy storage (CANMX). The most sensitive parameters for sediment simulation are USLE land cover factor for wood and shrubland (WSEV), the linear re-entrainment parameter for channel sediment routing (SPCON), channel 


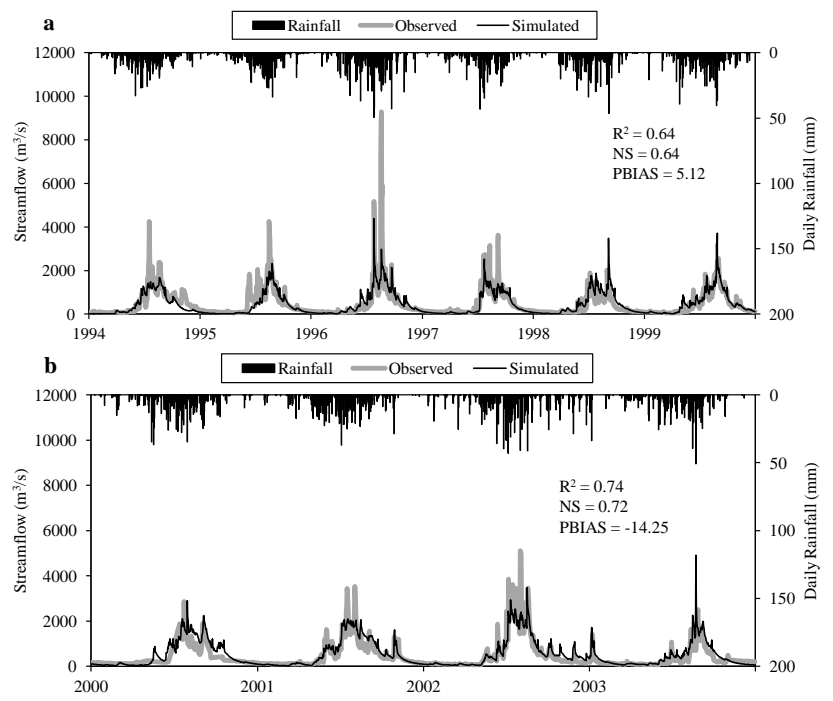

Fig. 7. Daily rainfall and comparison of measured and simulated daily flows for (a) calibration and (b) validation periods.

erodibility factor (Ch_COV1) and channel cover factor (Ch_COV2).

Figure $7 \mathrm{a}$ and $\mathrm{b}$ compare simulated daily streamflow with observed data for the calibration and validation periods respectively. The simulated daily flow matches the observed values for the calibration period with $R^{2}=0.64$, NS $=0.64$ and PBIAS $=5.12 \%$. For the validation period, the simulated and observed daily flows showed acceptable agreement as indicated by the values of $R^{2}$, NS and PBIAS being 0.74 , 0.72 and $-14.25 \%$ respectively. The results indicate that the Nam Ou SWAT model simulates the streamflow with reasonable accuracy. The observed total runoff volumes are captured well. The model is able to replicate the base flow well for both the calibration and validation periods. The cumulative plots of streamflow show that the model under predicted stream flow during calibration period while it overpredicted flow during the validation period (Fig. $8 \mathrm{a}$ and b), which is also reflected by the PBIAS value for both calibration and validation periods. Also, the model is not able to capture peak flows except for 1998 and 1999 during the calibration period and for 2000 and 2003 during the validation period. This mismatch in peak flows might be attributed to precipitation data and also errors in the observed streamflow data, especially during high flows. The SWAT modeling study in the Mekong River basin carried out by Rossi et al. (2009) had also reported that errors in gauging stations can attribute to less reliable matching of hydrographs, especially at sites along the Mekong's tributaries. The errors in gauging stations vary across the flow range but are more pronounced at extreme low flows due to recording errors and at high flows due to rating errors (Rossi et al., 2009). These behaviors could also demonstrate some floodplain features/processes that are not well characterized, i.e., consecutive flood-prone
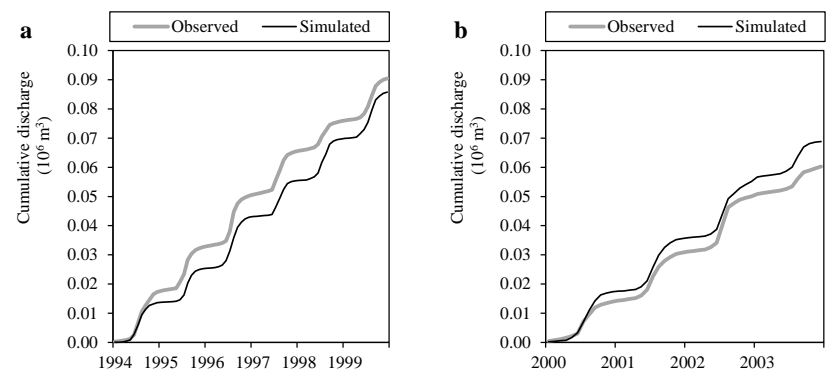

Fig. 8. Comparison of measured and simulated cumulative daily flows for (a) calibration and (b) validation periods.

areas activated, oxbows or even local occupations, which accelerate flows.

Figure 9 compares observed and simulated sediment yields. The $R^{2}$ and NS values are less than 0.6. However, the PBIAS value of $4.18 \%$ indicates a good volume balance between simulated and observed sediment loads. The lower values of NS and $R^{2}$ may be attributed to limitations in terms of the continuity and length of the records. Potter and Hiatt (2009) also reported lower $R^{2}$ and NS values for the daily sediment calibration of the Laguna de Santa Rosa watershed in Northern California for a similar reason - a limited number of sediment samples for calibration. This lack also highlights the need for further investigation in the quality of the observed sediment data reflected from the sampling process and the method of sediment analysis. Any attempt to assess changes in the sediment load of a river system is largely dependent upon the number and the location of the measuring stations, the amount of available data, reliability, accuracy, the temporal resolution of the data and the length of the record (Walling, 2008).

Figure 9 also shows that the model is not able to capture peak sediment events (sediments during the wet season). This underprediction of peak events can be due to an uncertainty in the soil erosion model used in SWAT. SWAT simulates erosion based on the MUSLE, which is originally developed to estimate annual soil loss from agricultural fields. Also, the topographic factor (LS) derived from DEM may not be accurate due to inaccuracies in DEM (Babel et al., 2011). Jackson et al. (1986) and Johnson et al. (1986) reported that the MUSLE tends to overpredict sediment yields for small events and underpredict the same for large events. The studied watershed is located in a tropical climate zone with intense rainfall and heavy storms, which have more potential to erode surface soil, but the MUSLE does not account for such factors (as is also mentioned by Phomcha et al., 2011). The high sediment yields during the wet season may be caused by effects that cannot be captured by the model, e.g., heavy (local) rainfall-induced landslides, river bank collapses or human activities. In general, the model is not able to capture the extremes as good as the mean values during the wet season. However, the model is able to capture the average system 
Table 4. Calibrated values of adjusted parameters.

\begin{tabular}{|c|c|c|c|}
\hline Variable & Parameter name & Description and units & $\begin{array}{r}\text { Fitted } \\
\text { parameter } \\
\text { value }\end{array}$ \\
\hline \multirow[t]{11}{*}{ Flow } & v_ALPHA_BF.gw ${ }^{a}$ & Baseflow alpha factor $(-)$ & 0.81 \\
\hline & v_RCHRG_DP.gw & Deep aquifer percolation fraction $(-)$ & 0.085 \\
\hline & r_CN2.mgt ${ }^{b}$ & Curve number $(-)$ & 0.0189 \\
\hline & v_CH_K2.rte & Channel effective hydraulic conductivity $\left(\mathrm{mm} \mathrm{h}^{-1}\right)$ & 3.15 \\
\hline & r_SOL_AWC.sol & Available water capacity $\left(\mathrm{mm} \mathrm{mm}^{-1}\right.$ soil $)$ & 0.261 \\
\hline & v_CH_N2.rte ${ }^{\mathrm{c}}$ & Manning's n-value for main channel (-) & 0.19 \\
\hline & v_SURLAG.hru & Surface runoff lag (days) & 11.69 \\
\hline & v_ESCO.hru & Soil evaporation compensation factor $(-)$ & 0.83 \\
\hline & r_SOL_K.sol & Saturated hydraulic conductivity $\left(\mathrm{mm} \mathrm{h}^{-1}\right)$ & 0.607 \\
\hline & v_GW_DELAY.gw & Groundwater delay time (days) & 51.79 \\
\hline & v_CANMX.hru & Canopy storage $(\mathrm{mm})$ & 2.04 \\
\hline \multirow[t]{4}{*}{ Sediment } & v_Usle_C (WSEV) & USLE land cover factor $(-)$ & 0.05 \\
\hline & v_SPCON.bsn & Linear re-entrainment parameter for channel sediment routing $(-)$ & 0.0025 \\
\hline & v_Ch_COV1.rte & Channel erodibility factor $(-)$ & 0.50 \\
\hline & v_Ch_COV2.rte & Channel cover factor $(-)$ & 0.18 \\
\hline
\end{tabular}

Note: ${ }^{\mathrm{a}}$ The extension (e.g., .gw) refers to the SWAT input file where the parameter occurs; ${ }^{\mathrm{b}}$ the qualifier (r-) refers to relative change in the parameter where the value from the SWAT database is multiplied by 1 plus a factor in the given range; ${ }^{c}$ the qualifier ( $\left.v_{-}\right)$refers to the substitution of a parameter by a value from the given range; and WSEV means wood shrub evergreen vegetation.

behavior reasonably well and this is most relevant for this study. This is expressed in the parameter PBIAS.

The $p$-factor, which is the percentage of observations bracketed by 95PPU, brackets $72 \%$ of the observations and $r$-factor equal to 0.49 for daily discharge, while for sediment yields the $p$-factor and $r$-factor are $83 \%$ and 0.68 respectively. Figures 10 and 11 show the uncertainty analysis results for monthly discharge and sediment yield of the study basin respectively. The number of days used for calculating the observed average sediment yield varied from 2 to 21 because of the sporadic nature of sediment measurements. As illustrated, a majority of the observed data are inside or very close to the predicted bands, thereby indicating good results. However, some peak events, mostly during the wet season (May-October), are outside the predicted bands for both discharge and sediment yields, and this implies the underestimation of these events by the model. For most cases, the uncertainty interval at the peaks is large. In general, the model performance, as represented by the $p$-factor and the $r$-factor, is reasonable. Large uncertainties in some events may also come from measurement errors associated with the system input (forcing) and output or due to inadequate climate or land use representations, as outlined by Schuol et al. (2008). This might also be due to the conceptual model uncertainties, because each hydrological model suffers from conceptual model uncertainties and this is particularly true for large watershed models where many processes (natural or man-made) may not be adequately represented in the model (Schuol et al., 2008; Vrugt et al., 2005; Uhlenbrook et al., 1999). In SUFI-2, the 95PPUs are the combined outcome of

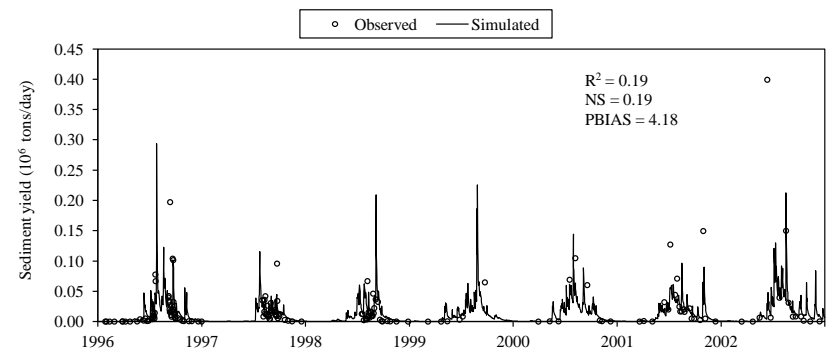

Fig. 9. Comparison of measured and simulated daily sediment yields for the calibration period.

the uncertainties in the conceptual model, parameters and input data. Nevertheless, these uncertainty sources are not separately evaluated but attributed as total model uncertainty, which is expressed through two parameters: $p$-factor and $r$-factor. Overall, the results above indicate that the SWAT model can be applied for a reasonable assessment of the climate change impact on river discharge and sediment yield in the basin.

\subsection{Impact of climate change on discharge}

For annual flows, the only simulation that projects a decrease comes from the CNRM-CM3 model, i.e., from the one that predicts a decrease in precipitation (Figs. 4 and 5) (Table 5). This decrease is projected for both time periods and varies from $6.6 \%$ to $17.1 \%$, depending on the particular scenario and time period. For the other models, increases varying from 


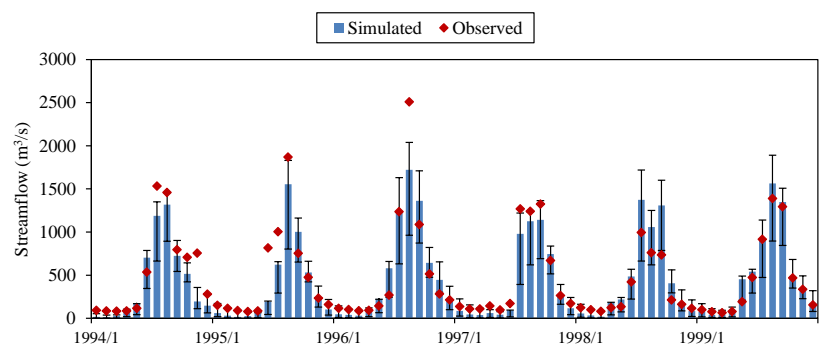

Fig. 10. Uncertainty analysis results of streamflow for the calibration period; the 95PPU band is shown by thin black bars.

$7.4 \%$ to $66.2 \%$ are projected. The intra-annual discharge changes range from $-44.2-87 \%$ in 2011-2040 and in between -62.4-104.9\% for 2041-2071 (Fig. 12). For 20112040 , the increase in discharge is more pronounced in October and the decrease is more pronounced at the end of the dry season (March-April) and the beginning of the wet season (May). In contrast, for 2041-2070, while the increase in discharge is more pronounced at the end of dry season (MarchApril), the decrease follows the same trend. Although the change is higher for March-April due to a larger percentage discharge change, more drastic changes in the magnitude of streamflow are estimated for months during the wet season (mostly July-October). This suggests that the change will be more significant for the wet season than the dry season.

The intra-annual (monthly) changes in the river discharge are greater as compared to the annual discharge changes. The climate change impact study (using the seven GCMs) conducted by Kingston et al. (2011) in the Mekong River basin similarly observed greater changes in mean monthly river discharge. Such changes may be attributed to the complex and contrasting sub-basin changes in precipitation and evaporation, as outlined by Kingston et al. (2011). These results suggest that it is important for planners to keep in mind the monthly changes when devising any water management strategies for the future. The projections of discharge changes in the basin are highly dependent on the direction of projected changes in precipitation. The variability observed in the intra-annual (monthly) change of streamflow can be attributed to the variable changes in intra-annual rainfall. The changes in monthly temperature and precipitation show that an increase in temperature occurs for the basin in all months of the year, but changes in precipitation vary from month to month within the basin and, consequently, from sub-basin to sub-basin.

The variation in simulated discharge between the climate models used in this study is significant, as it indicates a high degree of uncertainty in the direction of hydrological change due to climate change. The study by Kingston et al. (2011) in the Mekong River basin also concluded that there are significant uncertainties in the direction and magnitude of the change, and the variation in simulated discharge between several climate models is significant. Hence, it is

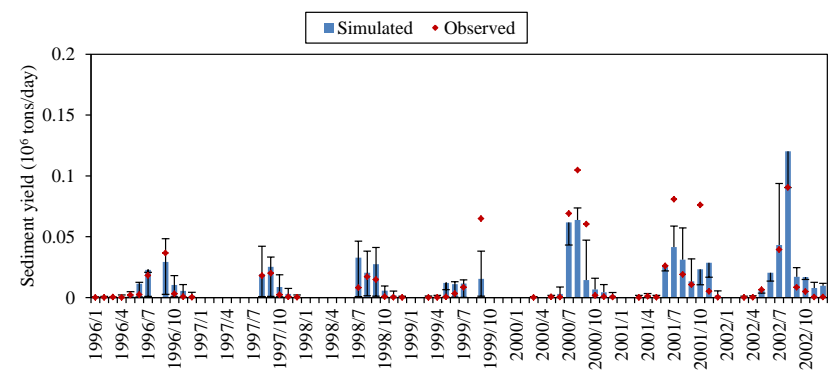

Fig. 11. Uncertainty analysis results of sediment yields for calibration period. The 95PPU band is shown by thin black bars. (Note that the number of days used for calculating average sediment yield varies from 2 to 21 because of sporadic nature of sediment measurements).

imperative that planners and decision-makers take this uncertainty into account in the design of the reservoir dams that have been planned for hydropower purposes, development of water management strategies and climate change adaptation activities (also mentioned by Lauri et al., 2012). Policy responses and priorities will differ depending on the degree of certainty with which a particular situation or issue is known, and where uncertainty is high there is need to factor uncertainty into planning (Johnston and Kummu, 2012).

\subsection{Impact of climate change on sediment yield}

The annual sediment yield change ranges from a $158.5 \%$ increase to a $26.9 \%$ decrease depending upon GHGES, climate models and time period (Table 5). The intra-annual (monthly) changes in sediment yield range from -81.8 to $242.5 \%$ for $2011-2040$ and -87.8 to $207.3 \%$ for $2041-2070$ (Fig. 13). Overall, the mean annual sediment cycle follows the trend of the mean annual discharge cycle. It can be also noted that, in general, the changes in the mean monthly sediment yield follow the same trend as the discharge; i.e., the change will be more significant for the wet season than for the dry season. Interestingly, the intra-annual changes in sediment yields are higher than the corresponding changes in discharge. This implies that the impact of climate changes on sediment yield is greater than on streamflow, because sediment yield increases more than linearly with an increase in flow (Naik and Jay, 2011).

An increase in flow discharge will, in general, increase the mean monthly, seasonal and annual sediment loads, while a decrease in the flow discharge will decrease the sediment loads for all scenarios, which is similar to the findings of the climate change impact study conducted by Phan et al. (2011) in the Song Cau watershed in northern Vietnam. Nevertheless, the study results indicate that the changes of sediment yield and discharge in response to climate change do not always happen in the same direction. For example, for the 2041-2070 PRECIS RCM A2 scenario, in the months of November and December, sediment yield seems to increase 
Table 5. Changes in average annual mean temperature, precipitation, discharges and sediment yield for all climate projections compared to the base period (1971-2000). Results are for 2011-2040 and 2041-2070 periods.

\begin{tabular}{|c|c|c|c|c|c|}
\hline Climate models & GHGES & $T_{\text {mean }}\left({ }^{\circ} \mathrm{C}\right)$ & Precipitation (\%) & Discharge (\%) & Sediment $(\%)$ \\
\hline \multicolumn{6}{|c|}{ 2011-2040 } \\
\hline \multirow[t]{3}{*}{ CGCM3.1 } & $\mathrm{A} 2$ & 1.54 & 28.84 & 49.00 & 114.83 \\
\hline & $\mathrm{A} 1 \mathrm{~b}$ & 1.56 & 35.94 & 62.28 & 158.49 \\
\hline & B1 & 1.47 & 31.16 & 54.32 & 143.05 \\
\hline \multirow[t]{3}{*}{ CNRM-CM3 } & A2 & 0.91 & -6.10 & -9.27 & -17.05 \\
\hline & $\mathrm{A} 1 \mathrm{~b}$ & 1.11 & -5.35 & -8.29 & -15.05 \\
\hline & B1 & 1.10 & -4.47 & -6.64 & -11.25 \\
\hline \multirow[t]{3}{*}{ MPI ECHAM5 } & $\mathrm{A} 2$ & 0.36 & 5.56 & 11.58 & 25.99 \\
\hline & $\mathrm{A} 1 \mathrm{~b}$ & 0.41 & 11.35 & 21.23 & 47.95 \\
\hline & B1 & 0.57 & 4.63 & 10.04 & 21.29 \\
\hline \multirow[t]{3}{*}{ NCAR CCSM3 } & $\mathrm{A} 2$ & 1.12 & 4.57 & 8.06 & 18.49 \\
\hline & $\mathrm{A} 1 \mathrm{~b}$ & 1.12 & 7.42 & 12.85 & 28.58 \\
\hline & B1 & 1.04 & 5.39 & 8.83 & 19.29 \\
\hline \multirow[t]{2}{*}{ PRECIS RCM } & $\mathrm{A} 2$ & 0.76 & 8.34 & 13.22 & 24.57 \\
\hline & B2 & 0.84 & 3.55 & 7.35 & 14.69 \\
\hline \multicolumn{6}{|c|}{$2041-2070$} \\
\hline \multirow[t]{3}{*}{ CGCM3.1 } & $\mathrm{A} 2$ & 2.46 & 32.90 & 55.17 & 147.15 \\
\hline & $\mathrm{A} 1 \mathrm{~b}$ & 2.36 & 29.99 & 51.58 & 142.03 \\
\hline & B1 & 1.95 & 25.09 & 44.41 & 123.65 \\
\hline \multirow[t]{3}{*}{ CNRM-CM3 } & A2 & 1.90 & -5.68 & -8.87 & -12.21 \\
\hline & $\mathrm{A} 1 \mathrm{~b}$ & 2.06 & -10.97 & -17.13 & -26.92 \\
\hline & B1 & 1.52 & -9.13 & -14.12 & -21.68 \\
\hline \multirow[t]{3}{*}{ MPI ECHAM5 } & $\mathrm{A} 2$ & 1.41 & 1.62 & 4.04 & 13.92 \\
\hline & Alb & 1.94 & 1.39 & 4.91 & 20.83 \\
\hline & B1 & 1.56 & -1.62 & -0.42 & 5.81 \\
\hline \multirow[t]{3}{*}{ NCAR CCSM3 } & $\mathrm{A} 2$ & 2.23 & -1.07 & -1.74 & -0.08 \\
\hline & $\mathrm{A} 1 \mathrm{~b}$ & 2.10 & 11.46 & 19.84 & 58.32 \\
\hline & B1 & 1.50 & -4.65 & -7.91 & -9.01 \\
\hline \multirow[t]{2}{*}{ PRECIS RCM } & $\mathrm{A} 2$ & 1.97 & 7.62 & 13.55 & 36.56 \\
\hline & B2 & 1.62 & 5.67 & 10.04 & 21.76 \\
\hline
\end{tabular}

even though water discharge decreases. For this period, the rainfall also decreases but temperature increases $(+1.6$ and $+1.9^{\circ} \mathrm{C}$ respectively). This result indicates that although there is decrease in rainfall the sediment still increases, which might be due to increase in temperature. Decrease in rainfall and increase in temperature may result in water stress, which reduces the growth of plants and hence aggravates the erosion rate. Study by Zhu et al. (2008) and Li et al. (2011) indicated that increased temperature may aggravate the soil erosion rate and, consequently, increase sediment flux through its influence on vegetation and weathering. The study conducted by Li et al. (2011) in the Lower Pearl River basin in China reported that an increase in temperature by $3{ }^{\circ} \mathrm{C}$ increases the sediment load by almost $14 \%$. For the CGCM3.1 A1b scenario, during May, although discharge increases, the sediment decreases. For this month, both rainfall and temperature increase. This indicates that increased rainfall does not necessarily increase soil loss. For May, it can be noted that about $13 \%$ increase in rainfall and nearly $+2.5^{\circ} \mathrm{C}$ shift in mean temperature results in predicted nearly $8 \%$ increase in streamflow. This clearly proves the significant influence of increased evaporation in the hydrological process of a basin. The decrease in sediment flux may be due to the significant influence of increased evapotranspiration and crop growth processes under warmer climate, as mentioned by Bogaart et al. (2003) in their study. Increased rainfall and increased temperature may accelerate the plant growth, which results less erosion. Changes in temperature and rainfall will affect the sediment transport capacity and erosion rate. This change in the sediment transport capacity and the erosion rate causes 

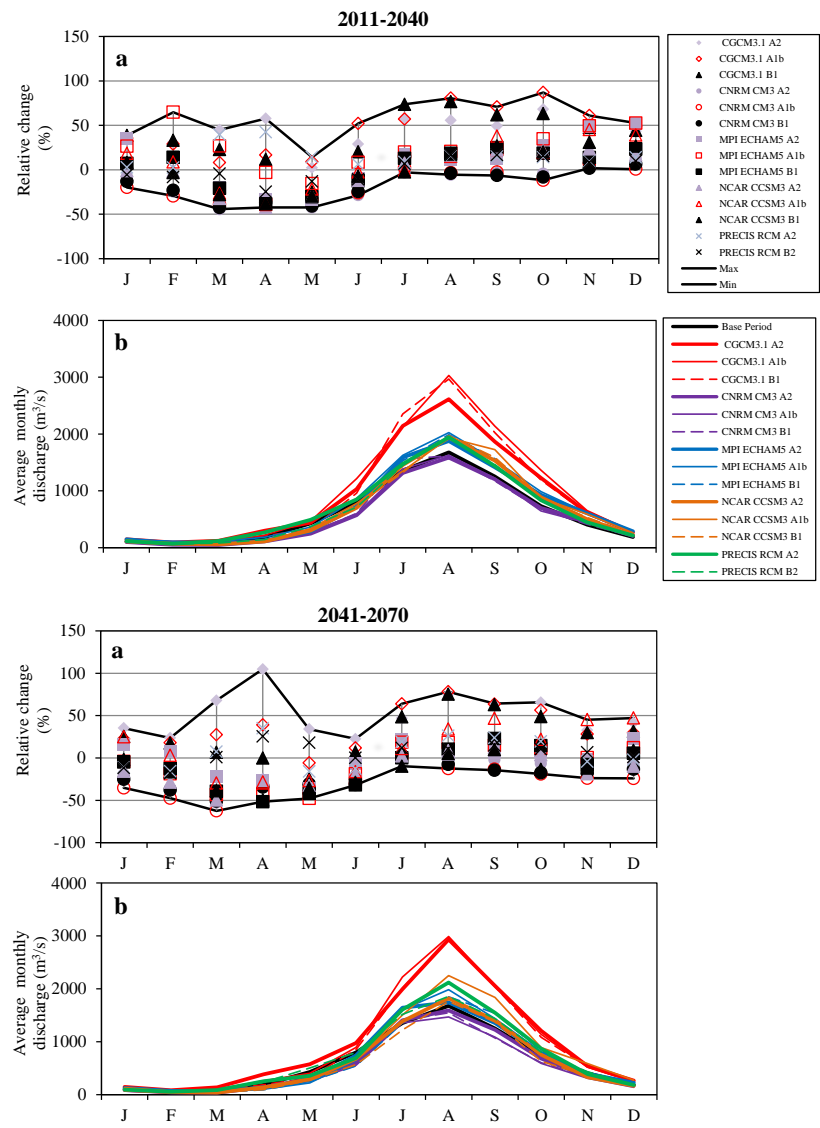

Fig. 12. (a) Change in future monthly streamflow for all climate projections relative to 1971-2000 and (b) annual discharge cycle for present (1971-2000) and for all climate projections. Results are for the 2011-2040 and 2041-2070 time periods.

changes in the sediment flux in a river, which is also outlined by Zhu et al. (2008).

Similar to discharge, the variation in simulated sediment between the climate models used in this study is significant, which indicates high uncertainty in the direction of sediment yield change due to climate change. This is also clearly indicated in a box and whisker plot (Fig. 14), where only maximum values of annual sediment loads are estimated to increase in the future, while the changes in medians, 25th percentiles, 75th percentiles and minimum values are not unidirectional.

Figure 15 is the longitudinal profile of the main stream, showing the locations of future reservoirs and their elevation relative to the basin outlet's datum. It also shows the averages of simulated annual sediment load (1971-2000) at future reservoir stations and changes in future sediment yield as compared to the 1971-2000 period under various GHGES, climate models and time scales. A significant change in mean annual sediment yield in each reservoir location has been observed. Increase in sediment yield is predicted to occur from less than $2 \%$ to more than $200 \%$, while the decrease
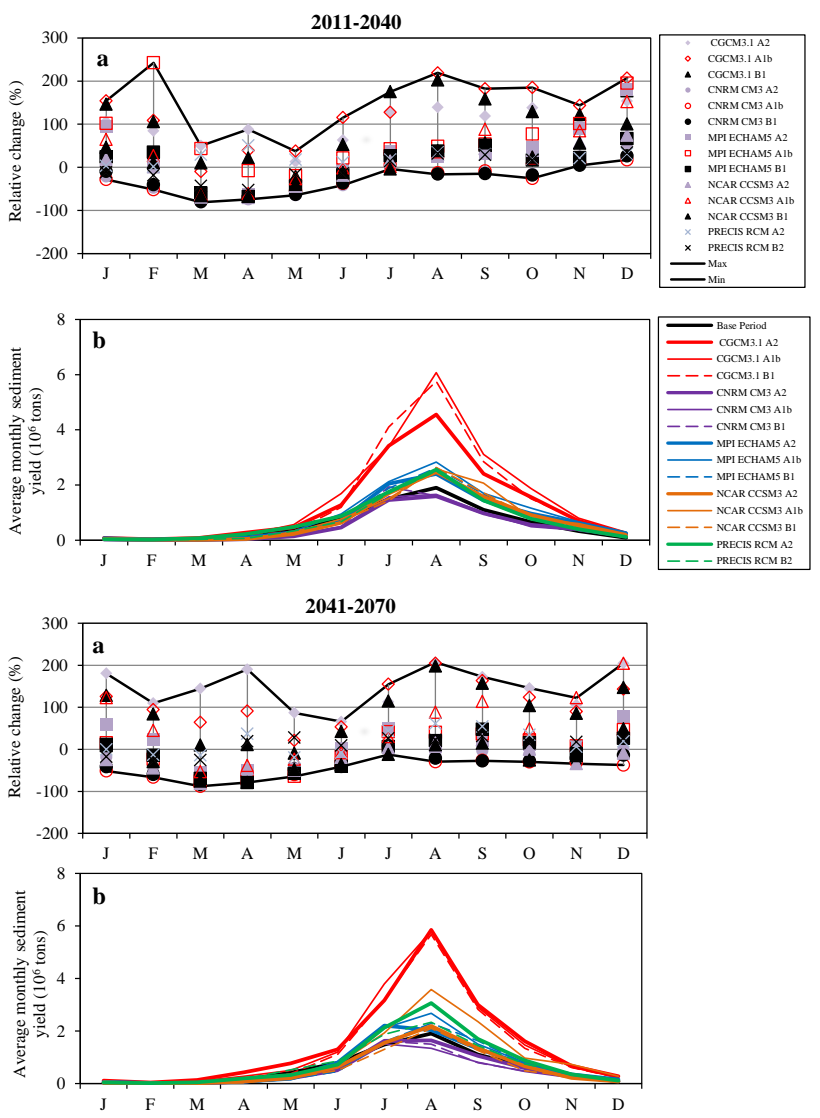

Fig. 13. (a) Change in future monthly sediment yield for all climate projections relative to 1971-2000 and (b) annual sediment yield cycle for present (1971-2000) and for all climate projections. Results are for the 2011-2040 and 2041-2070 time periods.

is predicted to occur from 10.6-29.7\% depending on scenarios, time period and locations. The estimations, however, do not consider the sediment trapping in the planned reservoirs; i.e., the reduction in suspended sediment by reservoirs is not considered in this study, or other changes related to, for instance, land use (e.g., change of the forest cover). In general, the range of change is higher in upstream dams and is reduced as it moves downstream, which may be due to variations in the rate of change of rainfall and soil loss from subbasin to sub-basin. Changes in sediment yields due to climate change in the future can have great implications for planned reservoirs and related sediment management. Increased sediment loads can intensify many problems linked to accelerated loss of reservoir storage through sedimentation and siltation or river channels and water distribution systems, an associated loss of conveyance capacity and increased turbidity of river water (Walling, 2008). Although decreasing sediment loads will frequently bring obvious benefits in terms of reduced sedimentation and siltation, it is important to recognize that there can also be negative impacts associated with reduced nutrient inputs to lakes, wetlands, floodplains, delta 

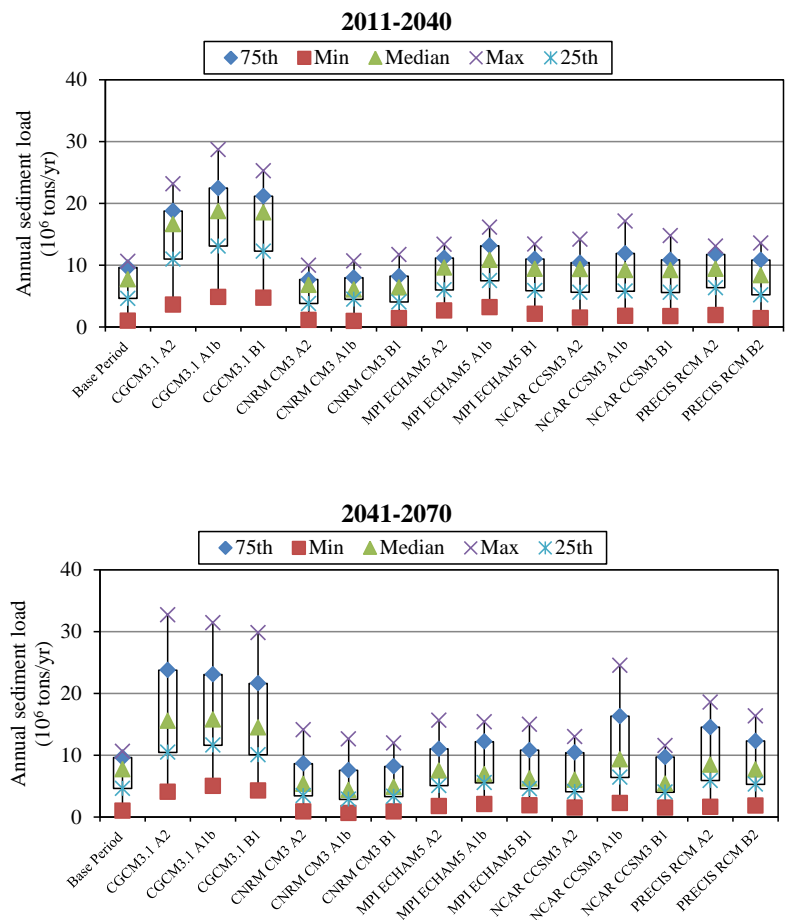

Fig. 14. Box and whisker plots of annual sediment load at gauging stations of Nam Ou for present climate (1971-2000) and for all climate projections. Results are for the 2011-2040 and 2041-2070 time periods.

and coastal areas, resulting in major ecosystem disturbances (e.g., Kummu and Varis, 2007; Kummu et al., 2008). Furthermore, decrease sediment load can cause sinking of deltas, change in river morphology due to erosion downstream of dams, and coastal erosion (e.g., Walling, 2008).

\subsection{Uncertainty in annual mean discharge and sediment yield}

Figure 16 shows the probability density functions (PDFs) for the mean annual discharge and the mean sediment yield. CGCM3 scenarios suggest both relatively large increases (more than $40 \%$ for the mean discharge and more than $100 \%$ for the sediment yield), while CNRM-CM3 scenarios and NCAR CCSM3 A2 and B1 suggest a decrease. The other climate model scenarios show relatively moderate increase in both mean discharge and sediments. Furthermore, the results show that the overall uncertainty of the hydrological variables increases with time (i.e., longer the prediction horizon, the larger the uncertainty), as most of the PDFs become flatter and inter-model variability also changes.

\subsection{Limitations of this study}

There are several limitations to the approach presented in this paper, whereby a major one is the use of the downscaling method. The change factor method only scales the mean,
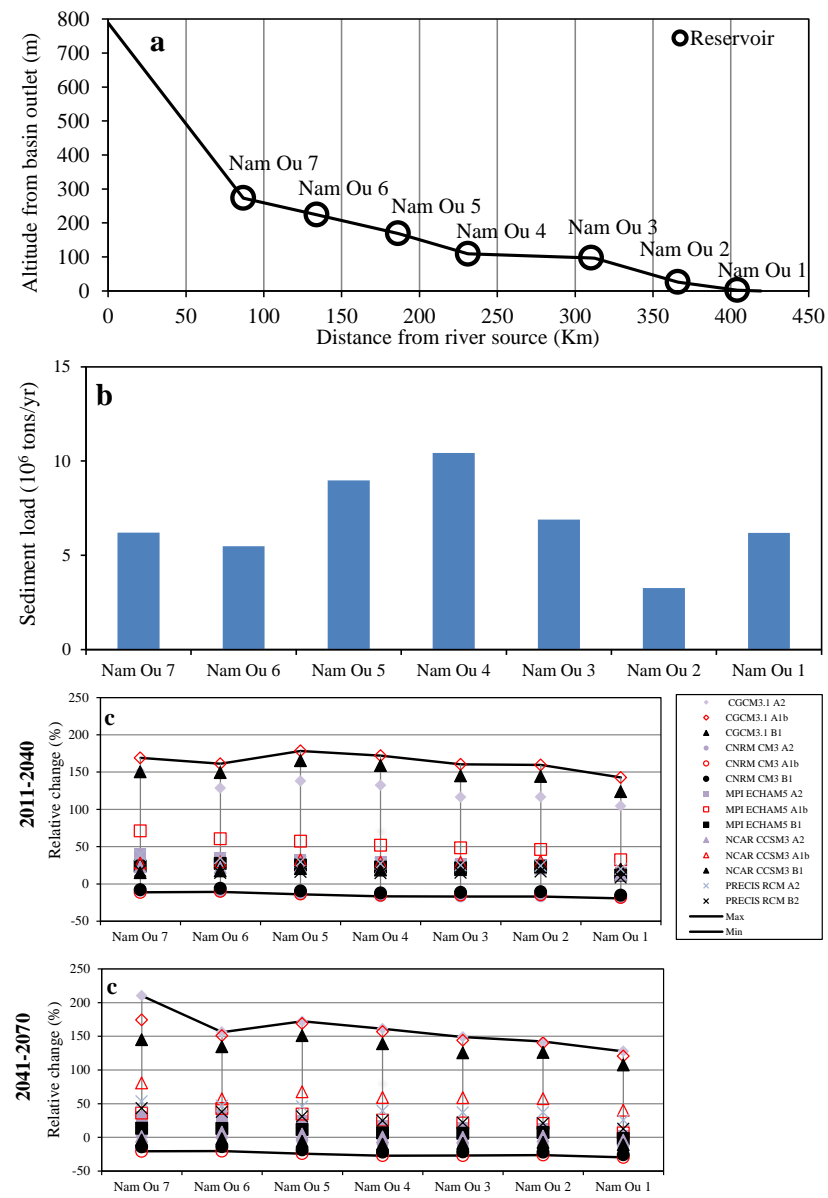

Fig. 15. (a) Longitudinal profile of the main stream showing the locations of planned reservoirs, and their elevation relative to the basin outlet datum. (b) Averages of simulated annual sediment load (1971-2000) at planned reservoir stations and (c) relative changes in future sediment yield as compared to 1971-2000 for all climate projections. Results are for the 2011-2040 and 2041-2070 time periods.

maxima and minima of climatic variables, ignoring changes in variability and assuming that the spatial pattern of climate will remain constant (Diaz-Nieto and Wilby, 2005). For example, the time series of precipitation occurrence will remain unchanged. This method will also not modify the variance of temperature data. In some applications, it may be just as important to evaluate changes in the variance of future climate variables and not only changes in the means (Semenov et al., 1998). Furthermore, for precipitation the temporal sequence of wet days is unchanged (Fowler et al., 2007). Besides the limitations, the change factor method also presents several advantages. It is a simple method to implement and only requires information from GCMs/RCMs at the monthly time scale. Most other statistical downscaling methods need data from GCMs at the daily time scale. Dailyscale data from GCMs are considered less accurate by many (Huth et al., 2001; Palutikof et al., 1997). Also, bias correction and variance adjustment is often needed to obtain merely 

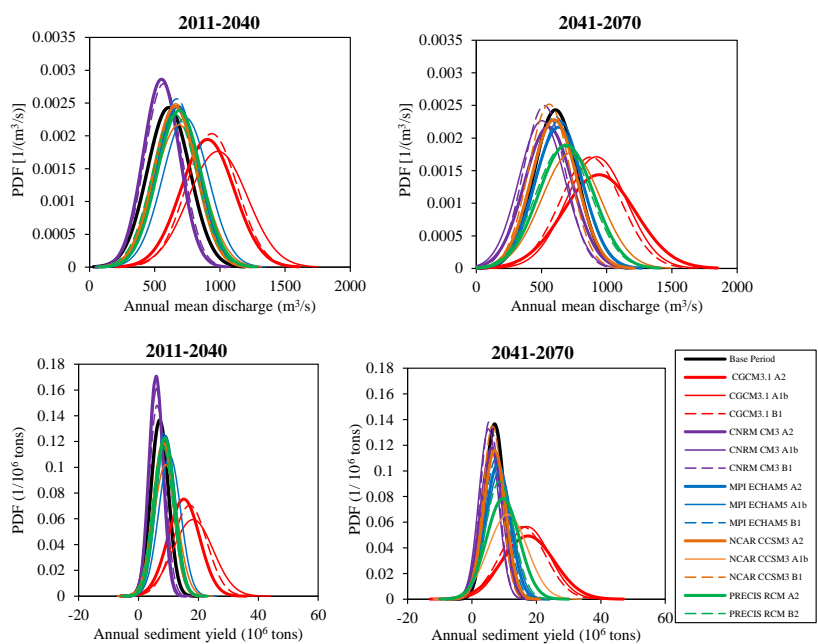

Fig. 16. Probability density functions of annual mean discharge and annual sediment yield data for all climate projections, and for the 1971-2000 as base period. PDFs are presented for the 2011-2040 and 2041-2070 time periods.

adequate results, whereas, with the change factor method, bias correction is implicitly built into the approach (Minville et al., 2008). For this study, the precipitation and temperature means are the key variables that need to be estimated, and hence the change factor method is appropriate. Furthermore, the daily-scale GCM data are not available for some GCMs and GHGES used for the study. However, variance of future sediment outputs and estimated flows derived from climate change runs are not discussed; hence we recommend applying empirical downscaling methods such as daily scaling or quantile mapping to global models so that variance can be better explained, in order to perform robust hydrological modeling related to river basin resilience.

Another limitation of this study is that the effect of uncertainty in model parameterization on the uncertainty of the projections of changes in discharge and sediment yield caused by climate change has not been analyzed. However it is expected that the uncertainty in model parameterization will impart little additional uncertainty to the climate change projections relative to that generated by GCMs, which is also agreed by previous studies (e.g., Prudhomme and Davies, 2009; Kingston et al., 2011).

Further, in this study only one hydrological and soil erosion (for sediment yield) model, SWAT, is used. A multimodel approach (Georgakakos et al., 2004) may be the best approach to better understand the uncertainty linked to the choice of models. This also provides an opportunity to select the most appropriate modeling tool for sediment simulation. Johnston and Kummu (2012) also stated that comparison of the basin-wide models in the Mekong is required to assess their strengths and weaknesses in different applications, identify the optimum suite of tools for different applications and help to quantify the error associated with different models. Finally this study does not take into account the effect of land use change on the sediment yield of the basin. The land use in the basin is assumed to remain the same in the future.

\section{Conclusions}

This study assesses the impact of climate change on sediment yield in the Nam Ou basin located in the northern part of Laos. In this study a multi-climate model, multi-emission scenario approach for the estimation of climate change impacts is used. The delta change method is used as a downscaling technique to generate future temperature and precipitation. The SWAT hydrological model is used to simulate the present and future changes in sediment yield in the study basin. Calibration, validation and uncertainty analyses for both discharge and sediment suggest that the SWAT model can be applied to simulate future changes in discharge and sediment yields due to eventual climate change.

Results indicate that large uncertainties exist in all the projected future hydrological variables (i.e., temperature, rainfall, discharge and sediment) due to differences between the climate model projections. Hence, it is impossible to predict future flows and sediment yields accurately. Despite this uncertainty, it has to be noted that projections of hydrological changes in the basin are highly dependent on the direction of the projected changes in precipitation; this is also concluded by Kingston et al. (2011). In general, higher discharge and sediment fluxes are expected during the wet season, although the percentage changes (not the absolute values) are found to be higher during the dry months. The climate impact on sediment yield is larger than on streamflow, and the changes do not always happen in the same direction. It is likely that such changes in sediment yield will have significant implications for both the ecology as well as anthropogenic development in the Nam Ou basin and further downstream in the Mekong basin. As the projected climate change impact on sediment varies remarkably between the different climate models, the uncertainty should be taken into account in both sediment management and climate change adaptation. Further, as the study results indicate that variation between climate models is significant, this study also emphasizes the need for a multiclimate model evaluation instead of just one climate model as has so far been mainly the case when estimating the possible climate change impacts to the Mekong hydrological variables (also mentioned by Lauri et al., 2012).

The results of this study may be helpful to development planners, decision makers and other stakeholders when planning and implementing appropriate basin-wide sediment management strategies as well as water management strategies to adapt to climate change. Moreover, some of the results show very high increases of erosion yields (up to $200 \%$ ), which should raise concern among the hydropower developers, as these particular results should cause planners to reassess the design, operation and sedimentation of future dams. 
Acknowledgements. The research presented in this paper is part of the PRoACC (Post-doctoral Programme on Climate Change Adaptation in the Mekong River basin) programme funded by the Netherlands Ministry of Development Cooperation (DGIS) through the UNESCO-IHE Partnership Research Fund. It was carried out jointly with UNESCO-IHE and Asian Institute of Technology, Thailand. It has not been subjected to peer and/or policy review by DGIS or UNESCO-IHE, and, therefore, does not necessarily reflect the views of these institutions. The authors would like to extend their appreciation to the Mekong River Commission for providing all the necessary data required for the study.

Edited by: N. Romano

\section{References}

Abbaspour, K. C.: SWAT-CUP2: SWAT calibration and uncertainty programs - A user manual, Department of Systems Analysis, Integrated Assessment and Modelling (SIAM), Eawag, Swiss Federal Institute of Aquatic Science and Technology, Duebendorf, Switzerland, 95 pp., 2008.

Abbaspour, K. C., Johnson, C. A., and Van Genuchten, M. T.: Estimating uncertain flow and transport parameters using a sequential uncertainty fitting procedure, Vadose Zone J., 3, 1340-1352, 2004.

Abbaspour, K. C., Yang, J., Maximov, I., Siber, R., Bogner, K., Mieleitner, J., Zobrist, J., and Srinivasan, R.: Modelling hydrology and water quality in the Pre-Alpine/Alpine Thur watershed using SWAT, J. Hydrol., 333, 413-430, 2007.

Adam, J. C. and Lettenmaier, D. P.: Adjustment of global gridded precipitation for systematic bias, J. Geophys. Res., 108, 42574271, 2003.

Akhtar, M., Ahmad, N., and Booij, M. J.: The impact of climate change on the water resources of Hindukush-KarakorumHimalaya region under different glacier coverage scenarios, J. Hydrol., 355, 148-163, 2008.

Arnold, J. G., Allen, P. M., and Bernhardt, G.: A comprehensive surface-groundwater flow model, J. Hydrol., 142, 47-69, 1993.

Arnold, J. G., Williams, J. R., and Maidment, D. R.: Continuoustime water and sediment routing model for large basins, J. Hydraul. Eng., 121, 171-183, 1995.

Arnold, J. G., Srinivasan, R., Muttiah, R., and Willams, J. R.: Large area hydrological modeling and assessment part I: model development, J. Am. Water Resour. As., 34, 73-89, 1998.

Babel, M. S., Shrestha, B., and Perret, S.: Hydrological impact of biofuel production: A case study of the Khlong Phlo Watershed in Thailand, Agr. Water Manage., 101, 8-26, 2011.

Benaman, J., Christine, A. S., and Douglas, A. H.: Calibration and validation of soil and water assessment tool on an agricultural watershed in upstate New York, J. Hydrol. Eng.-ASCE, 10, 363374, 2005.

Bogaart, P. W., Van Balen, R. T., Kasse, C., and Vandenberghe, J.: Process-based modeling of fluvial system response to rapid climate change - I: model formulation and generic applications, Quaternary Sci. Rev., 22, 2077-2095, 2003.

Boorman, D. B.: Climate, Hydrochemistry and Economics of Surface-water Systems (CHESS): adding a European dimension to the catchment modeling experience developed under LOIS, Sci. Total Environ., 314-316, 411-437, 2003.
Cai, X., Wang, D., Zhu, T., and Ringler, C.: Assessing the regional variability of GCM simulations, Geophys. Res. Lett., 36, L02706, doi:10.1029/2008GL036443, 2009.

Chen, J., Brissette, F. P., and Leconte, R.: Uncertainty of downscaling method in quantifying the impact of climate change on hydrology, J. Hydrol., 401, 190-202, 2011.

Diaz-Nieto, J. and Wilby, R. L.: A comparison of statistical downscaling and climate change factor methods: impacts on low flows in the river Thames, United Kingdom, Climate Change, 69, 245268, 2005.

Di Baldassarre, G., Elshamy, M., van Griensven, A., Soliman, E., Kigobe, M., Ndomba, P., Mutemi, J., Mutua, F., Moges, S., Xuan, Y., Solomatine, D., and Uhlenbrook, S.: Future hydrology and climate in the River Nile basin: a review, Hydrolog. Sci. J., 56, 199-211, 2011.

Eastham, J., Mpelasoka, F., Mainuddin, M., Ticehurst, C., Dyce, P., Hodgson,G., Ali, R., and Kirby, M.: Mekong River Basin Water Resources Assessment: Impacts of Climate Change, CSIRO: Water for a Healthy Country National Research Flagship, CSIRO, Australia, 2008.

Elshamy, M., Di Baldassarre, G., and van Griensven, A.: Characterizing climate model uncertainty using an informal Bayesian GLUE framework: an application to the River Nile, J. Hydrol. Eng., online first: doi:10.1061/(ASCE)HE.1943-5584.0000656, 2012.

Fowler, H. J., Blenkinsop, S., and Tebald, C.: Linking climate change modelling to impacts studies: recent advances in downscaling techniques for hydrological modeling, Int. J. Climatol., 27, 1547-1578, 2007.

Fuchs, H. J.: Data availability for studies on effects of land-cover changes on water yield, sediment and nutrients load at catchments of the Lower Mekong Basin, Working Paper 09, MRCGTZ Cooperation Programme, 2004.

Georgakakos, K. P., Seo, D., Gupta, H., Schaake, J., and Butts, M. B.: Towards the characterization of streamflow simulation uncertainty through multimodel ensembles, J. Hydrol., 298, 222-241, 2004.

Green, W. H. and Ampt, G. A.: Studies on soil physics, 1. The flow of air and water through soils, J. Agr. Sci., 4, 11-24, 1911.

Hanratty, M. P. and Stefan, H. G.: Simulating climate change effects in a Minnesota agricultural watershed, J. Environ. Qual., 27, 1524-1532, 1998.

Hardy, R. L.: Multiquadric equations of topology and other irregular surface, J. Geophys. Res., 76, 1905-1915, 1971.

Hargreaves, G. L., Hargreaves, G. H., and Riley, J. P.: Agricultural benefits for Senegal River Basin, J. Irrig. Drain. E.-ASCE, 111, 113-124, 1985.

Hay, L. E., Wilby, R. L., and Leavesly, H. H.: Comparison of delta change and downscaled GCM scenarios for three mountainous basins in the United States, J. Am. Water Resour. As., 36, 387397, 2000.

Hoanh, C. T., Jirayoot, K., Lacombe, G., and Srinetr, V.: Impact of climate change and development on Mekong flow regime, First assessment-2009, MRC Technical Paper No. 29, Mekong River Comission, Vientiane, Lao PDR, 2010.

Hu, Y., Maskey, S., and Uhlenbrook, S.: Downscaling daily precipitation over the Yellow River source region in China: a comparison of three statistical downscaling methods, Theor. Appl. Climatol., Online ISSN: 1434-4483, Springer Vienna, 
doi:10.1007/s00704-012-0745-4, 2012.

Huth, R., Kysely, J., and Dubrovsky, M.: Time structure of observed, GCM-simulated, downscaled, and stochastically generator daily temperature series, J. Climate, 14, 4047-4061, 2001.

IPCC (Intergovernmental Panel on Climate Change): Climate change: AR4 synthesis report, Cambridge University Press, Cambridge, 2007.

Ishidaira, H., Ishikawa, Y., Funada, S., and Takeuchi, K.: Estimating the evolution of vegetation cover and its hydrological impact in the Mekong River basin in the 21st century, Hydrol. Process., 22, 1395-1405, 2008.

Jackson, W. L., Gebhardt, K., and Haveren, B. P. V.: Use of the modified universal soil loss equation for average annual sediment yield estimates on small rangeland drainage basin, in: Symposium on Drainage Basin Sediment Delivery, IASH, Albuquerque, New Mexico, USA, 1986.

Johnson, C. W., Gordon, N. D., and Hanson, C. L.: North-west rangeland sediment yield analysis by the MUSLE, Transactions of the American Society of Agricultural and Biological Engineers, 26, 1889-1895, 1986.

Johnston, R. and Kummu, M.: Water resources models in the Mekong basin: a review, Water Resour. Manage., 26, 429-455, 2012.

Keskinen, M.: Water resources development and impact assessment in the Mekong Basin: which way to go?. Ambio, 37, 193-198, 2008.

Kiem, A. S., Ishidaira, H., Hapuarachchi, H. P., Zhou, M. C., Hirabayahi, Y., and Takeuchi, K.: Future hydroclimatology of the Mekong River basin simulated useing the high-resolution Japan Meteorological Agency (JMA) AGCM, Hydrol. Process., 22, 1382-1394, 2008.

Kingston, D. G., Thompson, J. R., and Kite, G.: Uncertainty in climate change projections of discharge for the Mekong River Basin, Hydrol. Earth Syst. Sci., 15, 1459-1471, doi:10.5194/hess-15-1459-2011, 2011.

Kummu, M. and Varis, O.: Sediment-related impacts due to upstream reservoir trapping, the Lower Mekong River, Geomorphology, 85, 275-293, 2007.

Kummu, M., Keskinen, M., and Varis, O.: Modern Myths of the Mekong. A critical review of water and development concepts, principles and policies. Water \& Development Publications Helsinki University of Technology, 206 pp., 2008.

Lauri, H., de Moel, H., Ward, P. J., Räsänen, T. A., Keskinen, M., and Kummu, M.: Future changes in Mekong River hydrology: impact of climate change and reservoir operation on discharge, Hydrol. Earth Syst. Sci. Discuss., 9, 6569-6614, doi:10.5194/hessd-9-6569-2012, 2012.

Li, Y., Chen, B.-M., Wang, Z.-G., and Peng, S.-L.: Effects of temperature change on water discharge, and sediment and nutrient loading in the lower Pearl River basin based on SWAT modeling, Hydrolog. Sci. J., 56, 68-83, 2011.

Lu, H.: Comparative analysis of the hydrological characteristics in Lancang Mekong River basin, International symposium of flooding in South Asia, Bangladesh, 1998.

Lu, X. X.: Spatial variability and temporal change of water discharge and sediment flux in the lower Jinsha tributary: impact of environmental changes, River Res. Appl., 21, 229-243, 2005.

Masih, I., Maskey, S., Uhlenbrook, S., and Smakhtin, V.: Impact of upstream changes in rain-fed agricultural water management on downstream flows in a semi-arid basin, Agr. Water Manage., 100, 36-44, doi:10.1016/j.agwat.2011.08.013, 2011a.

Masih, I., Maskey, S., Uhlenbrook, S., and Smakhtin, V.: Assessing the impact of areal precipitation input on streamflow simulations using the SWAT model, J. Am. Water Resour. As., 47, 179-195, doi:10.1111/j.1752-1688.2010.00502.x, 2011b.

Maurer, E. P.: Uncertainty in hydrologic impacts of climate change in the Sierra Nevada, California, under two emissions scenarios, Climatic Change, 82, 309-325, 2007.

Maurer, E. P., Adam, J. C., and Wood, A. W.: Climate model based consensus on the hydrologic impacts of climate change to the Rio Lempa basin of Central America, Hydrol. Earth Syst. Sci., 13, 183-194, doi:10.5194/hess-13-183-2009, 2009.

Mekong River Commission: MRC Work Programme, Mekong River commission, Vientiane, 2003.

Mekong River Commission: Overview of the Hydrology of the Mekong Basin, Mekong River Commission, Vientiane, 2005.

Mekong River Commission: Integrated Basin Flow Management, Social Team 2006 Final Report, Water utilization programenvironment program, Mekong River Commission, Vientiane, 2006.

Mekong River Commission: Existing, Under Construction and Planned/Proposed Hydropower Projects in the Lower Mekong Basin, September 2008, Map produced by the Mekong River Commission (MRC), available at: http://www.mrcmekong.org/ programmes/hydropower.htm (last access: 10 September 2011), 2008.

Menzel, L. and Burger, G.: Climate change scenarios and runoff response in the Mulde catchment (Southern Elbe, Germany), J. Hydrol., 267, 53-64, 2002.

Michael, A., Schmidt, J., Enke, W., Deutschlander, T., and Maltiz, G.: Impact of expected increase in precipitation intensities on soil loss results of comapritive model simulations, Catena, 61, 155-164, 2005.

Minville, M., Brissette, F., and Leconte, R.: Uncertainty of the impact of climate change on the hydrology of a Nordic watershed, J. Hydrol., 358, 70-83, 2008.

Monteith, J. L.: Evaporation and the environment, in: The State and Movement of Water in Living Organisms, 19th Symposia of the Society for Experimental Biology, Cambridge University Press, London, United Kingdom, 205-234, 1965.

Naik, P. K. and Jay, D. A.: Distinguishing human and climate influences on the Columbia River: changes in mean flow and sediment transport, J. Hydrol., 404, 259-277, 2011.

Nash, J. E. and Sutcliffe, J. V.: River flow forecasting through conceptual models. Part I - a discussion of principles, J. Hydrology, 10, 282-290, 1970.

Neitsch, S. L., Arnold, J. G., Kiniry, J. R., and Williams, J. R.: Soil and Water Assessment Tool theoretical documentation, version 2005, Texas Water Resources Institute, College Station, Texas, USA, 2005.

Nijssen, B., O’Donnell, G., Hamlet, A., and Lettenmaier, D.: Hydrologic sensitivity of global rivers to climate change, Climate Change, 50, 143-175, 2001.

O’Neal, M. R., Nearing, M. A., Vining, R. C., Southworth, J., and Pfeifer, R. A.: Climate change impacts on soil erosion in Midwest United States with changes in crop management, Catena, 61, 165-184, 2005. 
Palutikof, J. P., Winkler, J. A., Goodess, C. M., and Andresen, J. A.: The simulation of daily temperature time series from GCM Output. Part 1: comparison of model data with observations, J. Climate, 10, 2497-2513, 1997.

Phan, D. B., Wu, C. C., and Hsieh, S. C.: Impact of climate change on stream discharge and sediment yield in Northern Viet Nam, Water Res., 38, 827-836, 2011.

Phomcha, P., Wirojanagud, P., Vangpaisal, T., and Thaveevouthti, T.: Predicting sediment discharge in an agricultural watershed: a case study of the Lam Sonthi watershed, Thailand, Science Asia, 37, 43-50, 2011.

Potter, C. and Haitt, S.: Modeling river flows and sediment dynamics for the Laguna de Santa Rosa watershed in Northern California, J. Soil Water Conserv., 64, 389-393, 2009.

Priestley, C. H. B. and Taylor, R. J.: On the assessment of surface heat flux and evaporation using large-scale parameters, Mon. Weather Rev., 100, 81-92, 1972.

Prudhomme, C. and Davies, H.: Assessing uncertainties in climate change impact analyses on the river flow regimes in the UK. Part 1: baseline climate, Climate Change, 93, 177-195, doi:10.1007/s10584-008-9464-3, 2009.

Prudhomme, C., Jakob, D., and Svensson, C.: Uncertainty and climate change impact on the flood regime of small UK catchments, J. Hydrol., 277, 1-23, 2003.

Pruski, F. E. and Nearing, M. A.: Climate-induced changes in erosion during the 21 st century for eight US locations, Water Resour. Res., 38, 34.1-34.11, 2002.

Roberts, T.: Downstream ecological implications of China's Lancang Hydropower and Mekong Navigation Project, International Rivers Network (IRN), 2001.

Rossi, C. G., Srinivasan, R., Jirayoot, K., Duc, T. Le., Souvannabouth, P., Binh, N., and Gassman, P. W.: Hydrologic evaluation of the Lower Mekong River Basin with the soil and water assessment tool model, International Agricultural Engineering Journal, 18, 1-13, 2009.

Santhi, C., Arnold, J. G., Williams, J. R., Dugas, W. A., Srinivasan, R., and Hauck, L. M.: Validation of the SWAT model on a large river basin with point and nonpoint sources, J. Am. Water Resour. As., 37, 1169-1188, 2001.

Schuol, J., Abbaspour, K. C., Srinivasan, R., and Yang, H.: Estimation of freshwater availability in the West African sub-continent using the SWAT hydrologic model, J. Hydrol., 352, 30-49, 2008.

Semenov, M. A., Brooks, R. J., Barrow, E. M., and Richardson, C. W.: Comparison of the WGEN and LARS-WG stochastic weather generators for diverse climates, Climate Res., 10, 95107, 1998.

Setegn, S. G., Dargahi, B., Srivivasan, R., and Melesse, A. M.: Modeling of sediment yield from Anjeni-Gauged watershed, Ethiopia using SWAT model, J. Am. Water Res. As., 46, 514-526, 2010.

Shaw, E. H. and Lynn, P. P.: Areal rainfall using two surface fitting techniques, Bulletin of the International Association and Hydrological Science, XVII, 4-12, 1972.
SWCS: Conservation implications of climate change: soil erosion and runoff from cropland, Soil and Water Conservation Society, Ankeny, 2003.

Syvitski, J. P. M., Kettner, A. J., Peckham, S. D., and Kao, S. J.: Predicting the flux of sediment to the coastal zone: application to the Lanyang watershed, Northern Taiwan, J. Coastal Res., 21, 580-587, 2005.

USDA-SCS (United States Department of Agriculture - Soil Conservation Service): National engineering handbook, Section 4 Hydrology, Chapter 4-10, USDA-SCS, Washington, USA, 1972.

Uhlenbrook, S., Seibert, J., Leibundgut, C., and Rodhe, A.: Prediction uncertainty of conceptual rainfall-runoff models caused by problems to identify model parameters and structure, Hydrolog. Sci. J., 44, 279-299, 1999.

Van Liew, M. W., Veith, T. L., Bosch, D. D., and Arnold, J. G.: Suitability of SWAT for the conservation effects assessment project: a comparison on the USDA-ARS experimental watersheds, J. Hydrol. Eng., 12, 173-189, 2007.

Vrugt, J. A., Diks, C. G. H., Gupta, H. V., Bouten, W., and Verstraten, J. M.: Improved treatment of uncertainty in hydrologic modeling: combining the strengths of global optimization and data assimilation, Water Resour. Res., 41, 1-17, doi:10.1029/2004WR003059, 2005.

Wang, J. J., Lu, X. X., and Kummu, M.: Sediment load estimates and variations in the Lower Mekong River, River Res. Appl., 27, 33-46, 2011.

Walling, D. E.: The changing sediment load of the Mekong River, Ambio, 37, 150-157, 2008.

Williams, J. R.: Flood routing with variable travel time or variable storage coefficients, T. ASAE, 12, 100-103, 1969.

Williams, J. R.: Sediment-yield prediction with universal equation using runoff energy factor, Present and Prospective Technology for Predicting Sediment Yield and Sources: Proceedings of the Sediment Yield Workshop, USDA Sedimentation Lab., Oxford, Mississippi, 28-30 November 1972, ARS-S-40, 244-252, 1975.

$\mathrm{Xu}$, J. X.: Sediment flux to the sea as influenced by changing human activities and precipitation: example of the Yellow River, China, Environ. Manage., 31, 328-341, 2003.

Yang, J., Reichert, P., Abbaspour, K. C., Xia, J., and Yang, H.: Comparing uncertainty analysis techniques for a SWAT application to the Chaohe Basin in China, J. Hydrol., 358, 1-23, 2008.

Zhang, X. C., Srinivasan, R., and Hao, F.: Predicting hydrologic response to climate change on the Luohe River Basin using the SWAT model, American Society of Agricultural and Biological Engineers, 50, 901-910, 2007.

Zhang, X. C. and Nearing, M. A.: Impact of climate change on soil erosion, runoff, and wheat productivity in central Oklahoma, Catena, 61, 185-195, 2005.

Zhu, Y.-M., Lu, X. X., and Zhou, Y.: Sediment flux sensitivity to climate change: a case study in the Longchuanjiang catchment of the upper Yangtze River, China, Global Planet. Change, 60, 429-442, 2008. 